\title{
Does risk sorting explain bubbles?
}

\author{
HUBERT J. KISS - LÁSZLÓ Á. KÓCZY \\ ÁGNES PINTÉR - BALÁZS R. SZIKLAI
}




$$
\begin{aligned}
& \text { Discussion papers } \\
& \text { MT-DP - 2019/5 }
\end{aligned}
$$

Institute of Economics, Centre for Economic and Regional Studies, Hungarian Academy of Sciences

KTI/IE Discussion Papers are circulated to promote discussion and provoque comments.

Any references to discussion papers should clearly state that the paper is preliminary. Materials published in this series may subject to further publication.

Does risk sorting explain bubbles?

Authors:

Hubert J. Kiss

senior research fellow

Centre for Economic and Regional Studies

Hungarian Academy of Sciences

and Department of Economics, Eötvös Loránd University

kiss.hubert.janos@krtk.mta.hu

$$
\begin{gathered}
\text { László Á. Kóczy } \\
\text { senior research fellow }
\end{gathered}
$$

Centre for Economic and Regional Studies

Hungarian Academy of Sciences

Faculty of Economic and Social Sciences, Budapest University of Technology and Economics koczy.laszlo@krtk.mta.hu

Ágnes Pintér associate professor Department of Economic Analysis Universidad Autónoma de Madrid agnes.pinter@uam.es

Balázs R. Sziklai research fellow

Centre for Economic and Regional Studies

Hungarian Academy of Sciences, and Faculty of Economics, Corvinus University Budapest sziklai.balazs@krtk.mta.hu 


\section{Does risk sorting explain bubbles?}

Hubert János Kiss - László Á. Kóczy - Ágnes Pintér - Balázs R. Sziklai

\section{Abstract}

A recent stream of experimental economics literature studies the factors that contribute to the emergence of financial bubbles. We consider a setting where participants sorted according to their degree of risk aversion trade in experimental asset markets. We show that risk sorting is able to explain bubbles partially: Markets with the most risk-tolerant traders exhibit larger bubbles than markets with the most risk averse traders. In our study risk aversion does not correlate with gender or cognitive abilities, so it is an additional factor that helps understand bubbles.

Keywords: experiment, risk sorting, asset bubble

JEL classification: C91, G12 


\section{Magyarázza-e a kockázatkereső magatartás \\ a tőzsdebuborékok kialakulását?}

Kiss Hubert János - Kóczy Á. László - Pintér Ágnes - Sziklai R. Balázs

Összefoglaló

A kísérleti közgazdaságtan egyik kurrens témája azoknak a tényezóknek a kutatása, amelyek a tőzsdebuborékok kialakulásában szerepet játszhatnak. Kísérletünkben egy olyan környezetet vizsgálunk, amelyben a résztvevők a kockázatkerülésük mértéke szerint vannak beosztva piacokhoz, ahol értékpapírokkal kereskedhetnek. Megmutatjuk, hogy az egyének kockázati besorolása részben megmagyarázza a buborékok kialakulását: kockázatkereső egyénekből álló piacokon nagyobb buborékot figyelhetünk meg, mint kockázatkerülő egyének által alkotott piacokon. Tanulmányunkban a kockázatkerülés mértéke nem korrelál a résztvevők nemével vagy kognitív képességeivel, így ez egy új független tényező, ami rávilágít a buborékok kialakulására.

Tárgyszavak: kísérlet, kockázatkereső magatartás, tőzsdebuborék

JEL: C91, G12 


\title{
Does risk sorting explain bubbles?
}

\author{
Hubert J. Kiss ${ }^{1,2}$, László Á. Kóczy ${ }^{1,3}$, \\ Ágnes Pintér ${ }^{4}$, and Balázs R. Sziklai ${ }^{1,5}$ \\ ${ }^{1}$ Centre for Economic and Regional Studies, Hungarian Academy of Sciences and Deptartment of \\ Economics, Eötvös Loránd University, \\ ${ }^{2}$ Department of Economics, Eötvös Loránd University, \\ ${ }^{3}$ Department of Finance, Budapest University of Technology and Economics, \\ ${ }^{4}$ Department of Economic Analysis, Universidad Autónoma de Madrid, \\ ${ }^{5}$ Corvinus University of Budapest, Department of Operations Research and Actuarial Sciences,
}

\begin{abstract}
A recent stream of experimental economics literature studies the factors that contribute to the emergence of financial bubbles. We consider a setting where participants sorted according to their degree of risk aversion trade in experimental asset markets. We show that risk sorting is able to explain bubbles partially: Markets with the most risk-tolerant traders exhibit larger bubbles than markets with the most risk averse traders. In our study risk aversion does not correlate with gender or cognitive abilities, so it is an additional factor that helps understand bubbles.
\end{abstract}

Keywords: experiment, risk sorting, asset bubble

JEL-codes: C91, G12

Our economic history is a series of tragic collapses intermitting periods of growth. Perhaps the most spectacular elements of the crises are the asset bubbles: non-sustainable increases of asset prices that inevitably end in a crash. In the last decades experimental economics has proven to be a valuable tool in understanding why and how bubbles form. The experimental asset market literature studied — among other questions - how traits of the traders, expectations and features of the market mechanism affected the emergence of bubbles (Palan, 2013; Powell and Shestakova, 2016). 
Several recent experimental studies indicate that the sorting of participants may affect the formation of bubbles. The gender composition may influence the emergence of bubbles, as shown by Eckel and Füllbrunn (2015) and Cueva and Rustichini (2015). Bosch-Rosa et al. (2018) report that on markets composed of subjects with better cognitive abilities, no bubbles arise. Janssen et al. (2018) show that when sorting traders according to their speculative tendencies, markets with more speculative traders lead to larger bubbles.

We propose a new sorting that may explain the formation of bubbles and is both i) theoretically intuitive, ii) observable in real life, and iii) able to partially organize previous results. The basis of our sorting is risk tolerance, which according to our hypothesis is an important factor in the emergence of bubbles. The asset that is traded in the experimental markets is inherently risky, as it yields a stochastic dividend. By definition, more risktolerant traders value such an asset more in terms of utility. At the individual level, this higher valuation may translate into a willingness to pay a higher price for the asset and to sell the asset only at a higher price. If a market is populated with more risk-tolerant traders, then the market price that clears the market may be higher than in markets with more risk averse traders. Hence, we expect that sorting according to risk aversion is a potential source of bubbles.

Let us turn to the issue of whether such sorting goes on in real life. We consider first sorting according to the factors investigated by the literature. While there is a considerable imbalance in the gender composition in asset markets (Green et al. 2009 present such statistics), the clear (all-male vs. all-female) sorting assumed by Eckel and Füllbrunn (2015) is hard to imagine. Moreover, Eckel and Füllbrunn (2017) find that the difference vanishes when the gender composition is hidden from the participants. Real asset markets with sorting according to cognitive skills or speculative tendencies are even harder to imagine, and the studies that propose such kinds of sorting do not provide examples. Risk sorting, however, is a phenomenon that occurs naturally in asset markets, in at least two dimensions.

On the one hand, banks often draw up a risk profile of their customers wishing to trade on the stock market and try to dissuade those who are risk averse. They do this not only to protect the client but to comply with various international legal requirements. For instance, the Markets in Financial Instruments Directive (MiFID) in the EU prescribes the following guideline: 


\begin{abstract}
"When providing investment advice or portfolio management the investment firm shall obtain the necessary information regarding the client's or potential client's knowledge and experience in the investment field relevant to the specific type of product or service, that person's financial situation including his ability to bear losses, and his investment objectives including his risk tolerance so as to enable the investment firm to recommend to the client or potential client the investment services and financial instruments that are suitable for him and, in particular, are in accordance with his risk tolerance and ability to bear losses." (Article 25/2 of European Parliament (2014) )1
\end{abstract}

Such regulation implies that only sufficiently risk-tolerant retail investors are likely to be active in risky asset markets, so there is some risk sorting going on for retail investors.

On the other hand, there is some evidence that risk aversion also affects career choice in finance. Sapienza et al. (2009) find that MBA students with low risk aversion are more likely to pursue a risky finance career after graduation. This suggests that professionals in finance may have lower risk aversion than the average population, a sign of risk sorting. More generally, there is extensive evidence that self-selection into more risky activities occurs. Fossen (2012) presents ample empirical testimony that less risk averse individuals self-select into entrepreneurship (see Table 3.6 in Fossen 2012 for an overview). Moreover, Lazear and Shaw (2007) claim that firms choose compensation structures for their employees in a way to attract the individuals with the desired skills, hence, fostering self-selection.

Interestingly, risk tolerance may be an organizing principle behind some of the previous results. Sex and cognitive abilities often relate to each other. Males generally perform better in cognitive tasks (Frederick, 2005). Hence, according to Bosch-Rosa et al. (2018), males could be expected to generate fewer and smaller bubbles, contrary to the findings of Eckel and Füllbrunn (2015). A possible way out of this conundrum is the association of these factors with risk aversion. It is well-established that, in general, females are more risk averse than males (e.g. Croson and Gneezy 2009, Eckel and Grossman 2008)2, and many studies find that cognitive abilities are negatively related to risk aversion (see, for instance, Burks et al. 2009, Dohmen et al. 2010, Benjamin et al. 2013, or Dohmen et al.

\footnotetext{
${ }^{1}$ Similar regulations are in place elsewhere, see for instance the Australian Financial Services Reform Act. The EU has similar rule for insurance and reinsurance product distribution, see Article 30/1 of (European Parliament, 2016).

${ }^{2}$ We note that Filippin and Crosetto $(2016)$ question the ubiquity of this finding.
} 
2018)3. Therefore, risk aversion is a potential factor that helps understand the mechanism behind the effect of gender and cognitive abilities. In fact, both Eckel and Füllbrunn (2015) and Bosch-Rosa et al. (2018) point out the importance of risk aversion, without explicitly assessing its effects.

Based on the previous considerations, we formulate two hypotheses. First, the risk tolerance of traders may affect the formation of bubbles. More precisely, we expect to see larger bubbles in markets populated by more risk-tolerant traders. Second, we hypothesize that the mechanism behind the previous conjecture is that more risk-tolerant traders are willing to i) pay higher prices for the experimental asset and ii) sell the experimental asset at a higher price. To test these hypotheses, we invited 96 participants to an experiment. In the first phase of the experiment, we let them play experimental games that measured their risk and uncertainty attitudes and cognitive abilities. Then, without making them aware of the fact, we sorted them into 12 experimental asset markets according to their risk tolerance; they traded on these markets in two rounds, each consisting of 15 periods. We focus on bubbles, that is, on the positive deviation from the fundamental value of the experimental asset.

Related to our first hypothesis, we find a significant difference between the markets populated by the most and least risk-tolerant traders, the bubbles being significantly larger in the first case. To see if our second conjecture holds, we use panel regressions to investigate how individual and market characteristics affect if buy/sell orders exceed the fundamental value. We find that more risk-tolerant individuals tend to submit more excessive buy orders, supporting the above mechanism. However, we do not find the same effect for sell orders. Reassuringly, throughout the analysis we document that cognitive abilities and gender play an important role in the formation of bubbles, in line with the existing literature. Looking at round 2, we observe that - again in line with the literature - bubbles decrease or disappear. However, it does not happen uniformly, as in the markets with the most risk-tolerant traders, we still observe bubbles, while in other markets they disappear.

The paper is structured as follows. First, we review the existing literature, and then, in section 2 we present the experimental design and state our basic hypotheses. Section 3 contains the results, and section 4 concludes.

\footnotetext{
${ }^{3}$ It should be noted that the literature is not unambiguous. Andersson et al. (2016) claim that there is no such relationship.
} 


\section{Related literature}

Here we briefly review the literature that is most related to our study. First, we present the results that show some effect of sorting along different dimensions on the formation and size of bubbles. Then, we summarize the findings on the role of risk attitudes in experimental asset markets.

Sorting occurs if traders are (more likely) selected along some features into the experimental asset market. Perhaps the most studied sorting is that according to experience. In their classic study Smith et al. (1988) find that the more experienced traders there are in the experimental market, the fewer/smaller bubbles form. Similar findings appear in Dufwenberg et al. (2005); King (1991); King et al. (1993); Lei and Vesely (2009), and van Boening et al. (1993) 4. Eckel and Füllbrunn (2015) are the first to study whether sorting based on gender has any effect on experimental asset markets. They use the canonical experimental asset market design from Smith et al. (1988), but their markets consist of all male or all female traders, which can be easily observed by the participants. Based on the gender differences in risk taking, they conjecture that all-male markets lead to larger bubbles than all-female markets. They provide convincing support for this hypothesis. Moreover, in a follow-up experiment and after analyzing many other studies, they find that the share of female traders in markets is negatively correlated with mispricing. Cueva and Rustichini (2015) also investigate how gender composition affects trading in experimental asset markets. Contrary to Eckel and Füllbrunn (2015), they find that there is no significant difference between all-male and all-female markets in terms of volatility and bubbles, but mixed-gender markets exhibit small deviations from the fundamental value, even after taking into account risk aversion and cognitive skills. Holt et al. (2017) find that when the fundamental value of the experimental asset is flat, then bubbles are ubiquitous and of similar magnitude for both genders, but they report larger bubbles for male-only groups when the fundamental value has a declining pattern. Wang et al. (2017) report that all-female markets in China generate comparable experimental bubbles to those produced by all-male markets. They also document gender difference when comparing similar markets in the US, hinting at the possibility that gender-related findings in financial markets may be sensitive to culture.

Bosch-Rosa et al. (2018) carry out a similar exercise, but they sort participants accord-

\footnotetext{
${ }^{4}$ There are some papers that find no mitigating effect of experience: e.g. Noussair and Powell (2010), Oechssler et al. (2011).
} 
ing to cognitive sophistication into markets. In the first part of their experiment, subjects play 4 games that allow them to construct an index of cognitive sophistication. Then, they classify the upper/lower 30 percent according to this index as having high/low cognitive sophistication and invite the participants to partake in an experimental asset market. They find that markets populated by subjects with low cognitive abilities exhibited the well-known bubble and crash patterns. However, no bubbles or crashes were observed on the markets with highly sophisticated participants. The authors also measured risk aversion that showed no significant correlation with cognitive abilities. This suggests that their result is not driven by correlation between cognitive abilities and risk aversion. Interestingly, Bosch-Rosa et al. (2018) find that average session risk aversion is significantly and negatively correlated with some bubble measures, hinting at the possibility that higher average risk aversion may lead to fewer/smaller bubbles. Hanaki et al. (2017) investigate if and how diversity in cognitive abilities affects mispricing in experimental asset markets. They find that heterogeneity in cognitive abilities leads to significantly larger mispricing than homogeneity (regardless of individuals' with low or high cognitive ability forming the market).

Regarding the effect of cognitive skills, Cueva and Rustichini (2015) and Breaban and Noussair (2015) report similar findings to Bosch-Rosa et al. (2018): An increase in the average cognitive skills is associated with a significant decrease of mispricing. In a recent paper Janssen et al. (2018) investigate if sorting according to speculative tendencies may lead to overpricing in experimental asset markets. They find higher overpricing in markets with traders who are more speculative according to a speculation elicitation task. In a similar way, Kocher et al. (2018) sort participants according to self-control and find that reduced self-control leads to market overpricing.

Turning to the effect of risk aversion: Early papers in the experimental asset market literature already point out the role of risk attitudes. Several authors (King et al., 1993; Porter and Smith, 1995; Miller, 2002; Porter and Smith, 2008) hypothesize that risk aversion causes prices to start out low and as subjects get acquainted with the trading mechanism, they become less risk averse, which in turn leads to increases in price and potential emergence of bubbles. More concretely, if risk averse subjects sell their assets early and then only participants with higher risk appetite trade, then prices may appreciate, leading to a bubble. Fellner and Macieiovskv (2007) analyze data of four published papers (El-Sehity et al., 2002; Kirchler and Maciejovsky, 2002; Kirchler et al., 
2005; Maciejovsky et al., 2007) to see if risk attitudes measured through binary lottery choices are systematically associated with market behavior. They find that the more risk averse a participant is, the less active she is in the market. They also report marked gender differences (women being more risk averse). One may conjecture that less trading activity mitigates the possibility of bubbles and in this sense risk aversion may lead to fewer/smaller bubbles. However, based on the data the authors cannot make such strong statements, while our study allows us to see if such a hypothesis is true. Breaban and Noussair (2015) find that the average risk aversion of participants correlates negatively with the price level, hence, leading to less mispricing. Risk aversion also affects trading behavior, as more risk averse subjects are more likely to sell assets and trade more on the fundamental value. However, Cueva and Rustichini (2015) find that risk aversion is not a good predictor of bubble measures. In all these studies there is no risk sorting, so no conclusion can be drawn on the effect of such (self-)selection. The only study we are aware of that investigates bubbles is a chapter in Dirk-Jan Janssen's PhD thesis (Janssen, 2017). They use the bomb risk elicitation task (Crosetto and Filippin, 2013) to form call markets according to risk tolerance. There are low/moderate and high risk averse markets. Contrary to us, they report no convincing relationship between individual and market average risk aversion and aggregate market outcomes. There are important differences between their and our design: (i) traders in their market start with the same endowment and (ii) endowments are reinstated after each period. It has yet to be seen if these differences explain the discrepancies between their and our results.

\section{Experimental design}

In May 2017 we invited 96 students with a wide range of majors (less than $10 \%$ with economics or business studies) to the Corvinus University of Budapest (Hungary) to a unique session. In the first part of the experiment, we elicited, in an incentivized way, their risk/uncertainty attitude and cognitive abilities, while in the second part of the experiment, they were sorted according to their risk tolerance and participated in experimental asset markets.

Mainly two trading institutions are used in the asset market literature: (continuous) double auction markets and call markets. We used the call market because due to the elicitation phase, the experiment was lengthy and call markets were easier to implement 
given the time constraint we had. Two recent surveys, Palan (2013) (see Observation 27) and Powell and Shestakova (2016) (see section 2.2.), show that there is no qualitative difference between the two institutions regarding outcomes. Contrary to some other studies that analyze call markets (e.g. Bosch-Rosa et al. 2018, Haruvy et al. 2007), we do not elicit price forecast. Hanaki et al. (2018b) find that if price forecasts are elicited and subjects are paid based on both forecasting and trading, then mispricing is enhanced.

The experiment was programmed and conducted with the experimental software $\mathrm{z}$ Tree (Fischbacher, 2007) and for the asset market we used a modified version of GIMS (Palan, 2015). In the experimental asset market, we implemented 12 independent call markets, each with 8 traders trading 16 assets. The experiment lasted about 2 hours and consisted of two parts.

\subsection{Eliciting Individual Characteristics}

In the first part of the experiment, upon arrival participants were seated randomly at a computer in one of the four rooms used in the experiment. Once all the subjects were ready, the instructions for the first part were read aloud and questions were answered privately. Subjects were informed that the experiment would consist of two parts. Moreover, they learnt from the experimenter that from the tasks of the first part one would be randomly chosen and paid at the end of the experiment. The main objective of the first part of the experiment was to evaluate several individual characteristics of the subjects. In particular, we were interested in the (i) risk attitude, (ii) decisions in situations with strategic uncertainty, (iii) cognitive abilities, and (iv) choices under uncertainty. Hence, subjects started with completing a version of the Ellsberg two-color choice task. In this task there is a bag containing 10 black and 10 red balls. Participants are endowed with 1489 Tokens and choose one of the colors and the amount to bet on the chosen color. We used 1489 Tokens as endowment because it is not a round number in the sense that it does not end in zero(s), so it is not so easy to make focal decisions (e.g. risking half of the endowment). If the subject correctly guesses the color of the ball, which is randomly selected by the computer, she earns 2.5 times her bet, and otherwise, the money is lost. The amount of the bet is a natural measure of risk aversion: the less a participant bets, the more risk-averse she is. Afterwards the subjects played the Stag Hunt game with a randomly chosen partner. With this game we attempted to capture their 
attitudes to strategic uncertainty that may affect behavior in asset markets as well (see Akivama et al. 2017 or Hanaki et al. 2018a). Next followed the Cognitive Reflection Test (Frederick, 2005) to assess subjects' cognitive abilities. At the end, in order to evaluate the attitude of subjects regarding uncertainty, they played a modified version of the first task: where the distribution of the two colors was unknown. The translation of all four tasks can be found in full detail in Appendix A,

At the end of the first part of the experiment, subjects were informed about their performance in all four tasks (in Tokens) and about the randomly chosen task for which they would receive payment at the end of the experiment. To sort participants into experimental asset markets we used the risk attitude measure. In Table 1 we show the characteristics of the markets based on the tasks in phase 1 of the experiment.

\begin{tabular}{|c|c|c|c|c|c|c|c|c|}
\hline \multirow{2}{*}{ 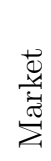 } & \multicolumn{2}{|c|}{$\begin{array}{c}\text { Risk } \\
\text { attitude }\end{array}$} & \multicolumn{2}{|c|}{$\begin{array}{c}\text { Table } \\
\text { Uncertainty } \\
\text { attitude }\end{array}$} & \multirow{2}{*}{$\begin{array}{l}\text { 1: Attituc } \\
\text { Strategic } \\
\text { uncertainty } \\
\text { (chose A) }\end{array}$} & \multicolumn{2}{|c|}{$\begin{array}{l}\text { es and abili } \\
\text { Cognitive } \\
\text { abilities }\end{array}$} & \multirow{2}{*}{ 过 } \\
\hline & Average & SD & Average & $\mathrm{SD}$ & & Average & $\mathrm{SD}$ & \\
\hline 1 & 1433.25 & 103.837 & 873.625 & 629.376 & $75.0 \%$ & 1.875 & 1.642 & $50.0 \%$ \\
\hline 2 & 1006.125 & 17.732 & 580.375 & 397.825 & $50.0 \%$ & 0.875 & 0.835 & $25.0 \%$ \\
\hline 3 & 799.375 & 21.784 & 710 & 230.770 & $50.0 \%$ & 1.125 & 1.246 & $75.0 \%$ \\
\hline 4 & 744.375 & 2.504 & 652.125 & 139.697 & $37.5 \%$ & 2.125 & 1.126 & $62.5 \%$ \\
\hline 5 & 700 & 0.000 & 605.625 & 179.592 & $62.5 \%$ & 1.625 & 1.685 & $75.0 \%$ \\
\hline 6 & 609.875 & 62.382 & 486.125 & 246.803 & $87.5 \%$ & 1 & 1.309 & $25.0 \%$ \\
\hline 7 & 500 & 0.000 & 554.875 & 105.918 & $50.0 \%$ & 1.625 & 1.061 & $50.0 \%$ \\
\hline 8 & 467.5 & 36.571 & 521.375 & 243.966 & $37.5 \%$ & 2.375 & 1.061 & $0.0 \%$ \\
\hline 9 & 387.5 & 23.146 & 381.25 & 125.178 & $37.5 \%$ & 1.125 & 0.835 & $87.5 \%$ \\
\hline 10 & 268.75 & 37.201 & 318.75 & 217.021 & $62.5 \%$ & 2.5 & 0.926 & $50.0 \%$ \\
\hline 11 & 182.75 & 29.688 & 151.5 & 160.104 & $37.5 \%$ & 1.625 & 1.408 & $37.5 \%$ \\
\hline 12 & 38.75 & 43.239 & 172.875 & 255.259 & $37.5 \%$ & 2.125 & 1.458 & $50.0 \%$ \\
\hline
\end{tabular}

Note that in Market 1, which is composed of the most risk-tolerant participants, traders placed as bet more than $95 \%$ of their endowment in the task that measured risk attitudes. The corresponding number in Market 12, populated by the most risk averse traders, is about $2.5 \%$. This shows that the sorting into markets based on risk attitude led to markets with substantially different average risk characteristics. However, also note that differences between subsequent markets are not very sharp in some cases (e.g. markets 4 and 5 or markets 7 and 8 ). This suggests that even if there is significant difference between the markets with the most and the least risk-tolerant traders, there may be no difference between subsequent markets. 


\subsection{The Call Market}

The second part of the experiment consisted of the implementation of 12 call markets where the traders of a market could trade units of a risky asset (share) with other traders of the market. We used the data on the risk attitude indicator from the first part of the experiment to form 12 homogeneous asset markets by simply ranking subjects according to this variable and sorting them into groups of 8 . Therefore, in each market the participants exhibited a similar risk attitude. Groups were formed anonymously: Subjects were not informed either about the identity or any characteristic of the other traders in the market. Instructions for the second part - containing the detailed description of the functioning of the call markets - were read aloud, and all questions were answered. Subjects were informed that they would trade with the same traders during the twice repeated 15 trading periods, each lasting 90 seconds. It was also explained in the instructions that one of the two 15-period market rounds would be randomly chosen for payment at the end of the experiment. In order to ensure that subjects understand the task and get familiar with the design of the market page, they first played a practice period. At the beginning of the real market phase, traders were given a random amount of initial endowment, in a combination of units of assets and cash. In line with the existing literature, we defined three endowment types that were the same in all 12 markets and were distributed among the traders of a group in the following way:

$\begin{array}{ccc}\text { Asset (units) } & \text { Cash (in tokens) } & \text { Number of traders } \\ 1 & 4720 & 3 \\ 2 & 2920 & 2 \\ 3 & 1120 & 3\end{array}$

Subjects were told their own initial endowment and were informed that the other participants might have different initial endowments, but all with the same expected value.

In each trading period subjects could submit at most one buy order (i.e. quantity and a maximum unit price to buy) and/or one sell order (i.e. quantity and a minimum unit price to sell) with the only conditions being that (i) a trader's submitted selling price cannot be lower than her submitted buying price, and (ii) all submitted orders have to be in line with the actual endowment of the subject (e.g. no short-selling is allowed). 
Instructions stated clearly that submitting orders and trading is not compulsory (if, for example, prices are not attractive enough). Each trading period lasted 90 seconds, and orders could be submitted before the time expired. At the beginning of each trading period, subjects were informed about the quantity of assets and cash at their disposal. Once a trading period finished, the market price of the asset was determined by the computer and the endowment of the subjects was updated with the realized transactions of the period. Each asset held at the end of a trading period paid a stochastic dividend of either 0, 40, 140, or 300 Tokens with the same probability (i.e. expected dividend: 120 Tokens; this expected value was stated clearly in the instructions and on the trading screens). Subjects were informed at the end of each period about the market price of the asset, the number of shares they sold and/or bought in the actual period, the dividend achieved in the actual period, and the new (updated) amount of assets and cash at their disposal for trading in the next period. The asset has a buy-back value of 0 Token at the end of period 15, hence, the fundamental value $(\mathrm{FV})$ of the asset at the end of period $t$ is simply $120(16-t)$ Tokens. Once the first 15 -period round was over, subjects were informed about their gains, i.e. the total cash held at the end of period 15 (in Tokens). Finally, the market game was repeated (without changing the composition of the markets) once again, with the only difference being that the initial endowment of a subject could be different, as it was again randomly drawn from the same distribution.

After both market rounds finished, subjects were informed about their total payoff (in Tokens), which comprised the money won in the first part of the experiment (i.e. payment of one randomly chosen task), the gains of the randomly chosen market round (which turned out to be round 1), and the show-up fee of 3000 Tokens. Final payoffs were displayed on the last screen both in Token and in Hungarian Forint (HUF), the exchange rate being 3 Tokens $=1$ HUF. Average payoff was about 3750 HUF (the equivalent of about 12 EUR or 13.3 USD at that time).

\subsection{Hypotheses}

We formulate two broad hypotheses. The first concerns the relationship between risk tolerance and the emergence of bubbles, and the second describes a potential mechanism through which risk tolerance may affect the formation of bubbles.

Hypothesis 1 (Risk tolerance): Risk tolerance affects the formation of bubbles. We 
expect to see larger bubbles on markets populated with more risk-tolerant traders.

Hypothesis 1 simply states that we expect to see larger bubbles on markets with traders exhibiting more risk tolerance. Note that we do not formulate exactly how the relationship may be. We allow for a linear relationship, but potentially there is only difference on the extremes (as in Bosch-Rosa et al. 2018).

Hypothesis 2 (Buy and sell orders): We conjecture that more risk-tolerant traders value the asset traded on the experimental market more. Therefore, the more risk-tolerant a trader is, the higher price she is willing to pay for the asset. More concretely, higher risk tolerance may correlate with a higher positive deviation from the fundamental value. Similarly, the more risk-tolerant the trader is, the higher price she requires to sell the asset.

Hypothesis 2 specifies a potential channel through which hypothesis 1 may hold. The experimental asset used in the experiment yields a stochastic dividend that is inherently risky. By definition, the more risk-tolerant an individual is, the more she values such a risky investment in terms of utility. As a consequence, she may be willing to pay a higher price to obtain this asset than a more risk averse individual. Since we are interested in the formation of bubbles, we conjecture that higher individual risk tolerance is associated with higher buy order above the fundamental value. A similar story holds when selling the experimental asset. At an individual level, a more risk-tolerant trader is willing to sell the risky asset only at a higher price, so she submits a high sell order. Higher risk tolerance may correlate with higher sell orders above the fundamental value. These individual effects may aggregate on the market level. If there is a market with more risk-tolerant individuals than another market, then we expect that the higher individual willingness to both pay and sell at a higher price translates into a higher market price, ceteris paribus.

\section{Results}

In Table 2 we report the pairwise correlations between the individual characteristics of the participants. Risk attitude and choices under uncertainty are highly and positively correlated. Choice under uncertainty is weakly and negatively correlated with cognitive abilities and positively correlated with strategic uncertainty. Female participants tolerated significantly more uncertainty in task 4 but performed significantly worse than male 
subjects in the Cognitive Reflection Test. Importantly, risk tolerance did not correlate significantly either with cognitive abilities or with gender, so risk aversion cannot organize the results found in previous literature 5

Table 2: Pairwise correlation between individual characteristics

\begin{tabular}{|c|c|c|c|c|}
\hline & Risk & Uncertainty & $\begin{array}{c}\text { Cognitive } \\
\text { abilities }\end{array}$ & $\begin{array}{c}\text { Strategic } \\
\text { uncertainty }\end{array}$ \\
\hline Risk & - & & & \\
\hline Uncertainty & $0.5165^{* * *}$ & - & & \\
\hline Cognitive abilities & -0.1104 & $-0.1869^{*}$ & - & \\
\hline Strategic uncertainty & 0.1585 & $0.1731^{*}$ & 0.0319 & \\
\hline Female & 0.0042 & $0.2125^{* *}$ & $-0.2022^{* *}$ & -0.0822 \\
\hline
\end{tabular}

Next, in Figure 1 we show the evolution of the prices in phase 1. We group three markets together and depict the average prices of these markets and how prices evolve on them. Grouping three markets together is natural, as these groups were seated in the same room and they also represent quartiles. To assess the extent of bubbles/mispricing, we also plot the fundamental value.

Visual inspection suggests that in line with our conjecture bubbles in markets 1-3 (populated by the most risk-tolerant traders) are more pronounced than in other markets (except markets 7 and 9). Markets 7 and 9 do not exhibit the generally observed crash pattern 6

Measures that quantify the deviation from the fundamental value are generally known as bubble or mispricing measures. We believe that a distinction is warranted. The idea of bubble implies prices above the fundamental value, while mispricing encompasses any deviation from the fundamental value. Hence, bubble measures, contrary to mispricing measures, gauge only positive deviations from the fundamental value. Note that mispricing measures take into account the negative deviations that occur always at the beginning of the trading. However, these deviations are mainly due to the fact that in these initial periods subjects get acquainted with the trading mechanism. This learning process may make the mispricing measures noisy, which is why we give a larger weight to bubble

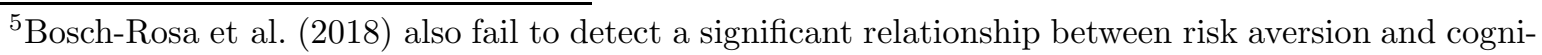
tive abilities. Horn and Kiss (2018) did not find significant association between gender and risk attitudes in a different experiment carried out with university students in Hungary.

${ }^{6}$ While this seems somewhat strange, it has been already observed in the literature. For instance, Smith et al. (1988) in their classic study find that professional and business people from the Tucson area generate a large bubble and no crash. Some of the all-female markets in Eckel and Füllbrunn (2015) also do not exhibit a crash at the end of the trading. Moreover, Lei et al. (2001) set up an environment in which speculation is impossible and even under such condition they document prices exceeding the maximum possible future dividend earnings.
} 
Figure 1: Price evolution. (Top left pane: markets 1-3 populated by the most risk-tolerant traders. Top right pane: markets 4-6, second most risk-tolerant set of markets. Bottom left pane: markets 7-9, third most risk-tolerant quartile of markets. Bottom right pane: markets 10-12 populated by the least risk-tolerant traders.)

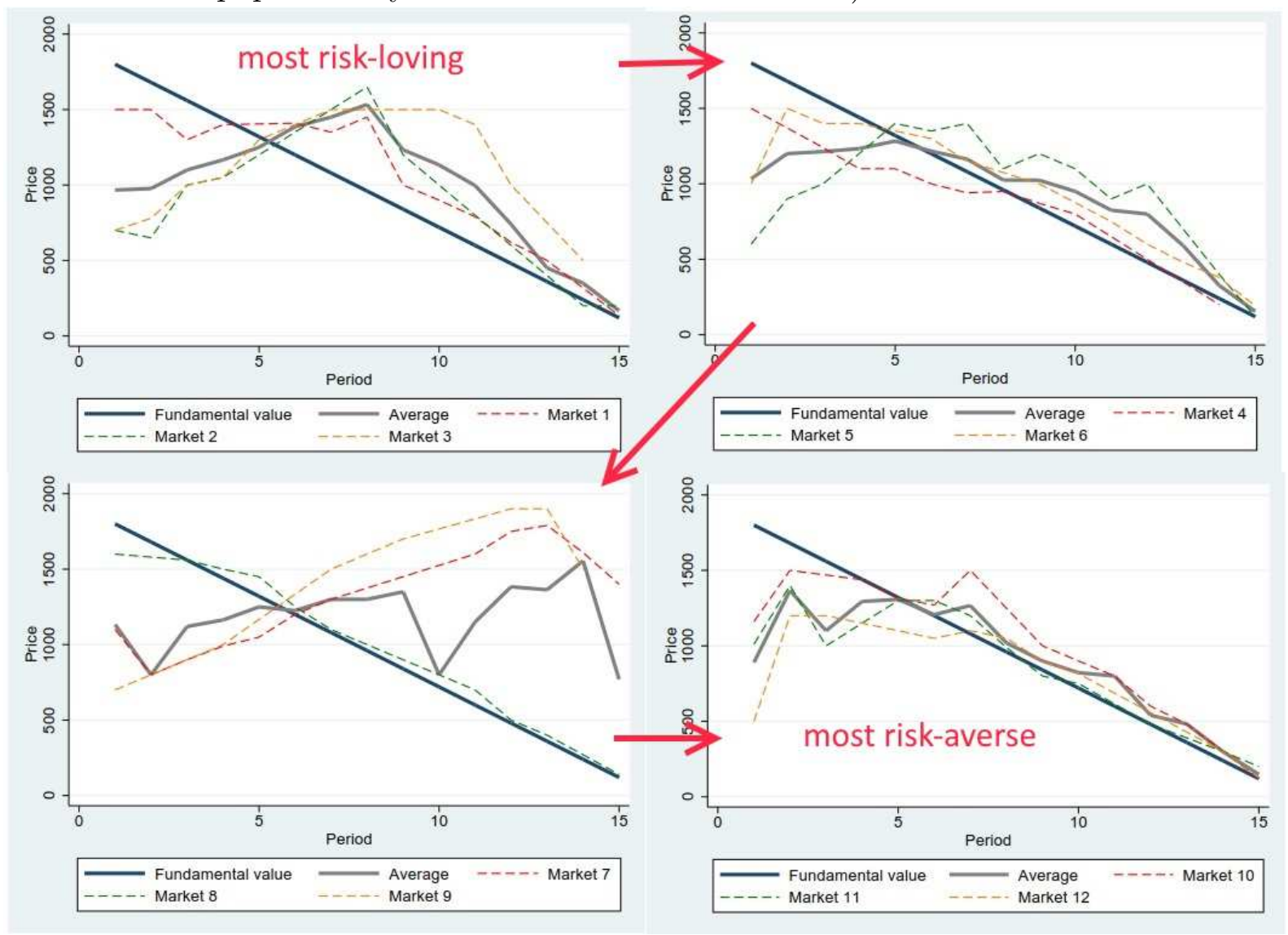

measures 7 For the same reason, we also exclude the first 5 periods from part of the analysis.

We consider three mispricing measures. Average Bias $\left(\sum_{t}\left(P_{t}-F V_{t}\right) / 15\right)$ averages the deviation of period price from period fundamental value. A large Average Bias indicates that prices tend to stay above fundamentals and, hence, signals bubbles, while an Average Bias close to zero shows the lack of mispricing. Note that an Average Bias close to zero may be due to the fact that negative deviations from the fundamental value at the beginning of the trading offset large positive deviations that occur later. Total Dispersion $\left(\sum_{t}\left|P_{t}-F V_{t}\right|\right)$ sums the absolute deviation of period price from period fundamental value and shows how close prices and fundamental values are to each other. The larger the value, the larger the mispricing. Amplitude $\left(\max _{t}\left\{\left(P_{t}-F V_{t}\right) / F V_{t}\right\}-\min _{t}\left\{\left(P_{t}-F V_{t}\right) / F V_{t}\right\}\right)$

\footnotetext{
7Janssen et al. (2018) also focus on "specific measures that describe fundamentally unjustified positive price deviations."
} 
measures the trough-to-peak change in market price relative to the fundamental value. Large amplitude suggests large volatility that is potentially due to bubble.

We consider the following bubble measures. Positive Deviation is similar to Total Dispersion, but it sums only the absolute per-period price deviations from the per-period fundamental value if prices are above the fundamental value 8 The larger the positive deviation, the larger the bubble. Boom Duration counts the maximum number of consecutive periods above the fundamental value. Longer boom duration is a sign of larger bubbles. We define a new measure of our own that is very similar to Amplitude. We call it Positive Amplitude, and it measures the maximum positive deviation from the fundamental value 9

There is another measure that is widely considered in the literature but is not based on deviation from the fundamental value. Turnover measures trading activity and is defined as the sum of all transactions divided by the number of shares in the market. High turnover implies high trading activity, which in turn is associated with mispricing/bubbles.

If we calculate the correlations between the previous measures (see Appendix $\mathrm{C}$ ), then we find that Positive Deviation is the most encompassing measure of bubbles/mispricing, as it correlates at at least 5 percent significance level with 4 other measures. Total Dispersion correlates very strongly with Positive Deviation and the amplitude measures (that are also associated at 5 per cent). Boom Duration correlates with at 5 per cent only with Average Bias, while Turnover is orthogonal to all other measures.

\subsection{Risk tolerance and bubble/mispricing measures}

Table 3 shows the value of the different bubble/mispricing measures. It also indicates the value of the Mann-Whitney U test, which compares the markets with the most risktolerant individuals (markets 1-3) with the markets formed by the most risk averse agents (markets 10-12).

If we ignore markets 7-9 because we do not observe the crash pattern in two of these three markets, then we find that the bubble/mispricing measures behave as expected: The average of the bubble/misprising measures decreases as the risk-tolerance of the markets

\footnotetext{
${ }^{8}$ There are modifications of this measure that use some normalization. Haruvy et al. (2007) divide our measure by the number of assets, while Bosch-Rosa et al. (2018) normalize with mean fundamental value in the market. These modifications do not change any of the results, as they only scale our measure.

${ }^{9}$ There are many other measures in the literature (Stöckl et al., 2010). Most of them are just transformations of the ones used.
} 
decreases. More precisely, the average of these measures is higher for markets 1-3 than for markets 4-6 or markets 10-12. Similarly, these averages for markets 4-6 are higher than for markets 10-12. Hence, in these bilateral comparisons the directions are as expected for all the measures.

Table 3: Observed values of bubble and mispricing measures. The last row shows the p-value of the Mann-Whitney U test comparing markets 1-3 to 10-12.

\begin{tabular}{|c|c|c|c|c|c|c|c|}
\hline \multirow[b]{3}{*}{ Market } & \multicolumn{3}{|c|}{ Bubble measures } & \multicolumn{3}{|c|}{ Mispricing measures } & \multirow[b]{3}{*}{ Turnover } \\
\hline & Positive & Boom & Positive & Average & Total & & \\
\hline & Deviation & Duration & Amplitude & Bias & Dispersion & Amplitude & \\
\hline$\overline{1}$ & 1795 & 8 & 490 & 78.08 & 2575 & 790 & 1.31 \\
\hline 2 & 2340 & 8 & 690 & -60 & 5580 & 1790 & 2.13 \\
\hline 3 & 4180 & 7 & 800 & 93.08 & 7150 & 1900 & 1.5 \\
\hline Avg 1-3 & 2771.67 & 7.67 & 660 & 37.05 & 5101.67 & 1493.33 & 1.65 \\
\hline 4 & 110.5 & 2 & 80 & -145.95 & 1680.5 & 420 & 1.31 \\
\hline 5 & 2750 & 10 & 520 & -2 & 5530 & 1720 & 1.5 \\
\hline 6 & 960 & 5 & 160 & -16.92 & 2140 & 960 & 1.94 \\
\hline Avg 4-6 & 1273.50 & 5.67 & 253.33 & -54.96 & 3116.83 & 1033.33 & 1.58 \\
\hline 7 & 7180 & 5 & 1430 & 324.62 & 10140 & 2310 & 1.75 \\
\hline 8 & 620 & 10 & 130 & 32.31 & 820 & 330 & 2 \\
\hline 9 & 6140 & 3 & 1540 & 306.00 & 9220 & 2640 & 1.13 \\
\hline Avg 7-9 & 4646.67 & 6 & 1033.33 & 220.97 & 6726.67 & 1760 & 1.63 \\
\hline 10 & 1272 & 5 & 420 & 37.08 & 2099 & 1060 & 1.75 \\
\hline 11 & 420 & 3 & 120 & -120 & 2400 & 910 & 1.5 \\
\hline 12 & 330 & 4 & 96 & -196.1 & 2621 & 1397 & 1.44 \\
\hline Avg 10-12 & 674 & 4 & 212 & -93.01 & 2373.33 & 1122.33 & 1.56 \\
\hline p-value & 0.0495 & 0.0463 & 0.0495 & 0.1266 & 0.1266 & 0.5127 & 1 \\
\hline
\end{tabular}

However, if we carry out the non-parametric Mann-Whitney U tests comparing markets 1-3, markets 4-6, and markets 10-12, then we only observe statistically significant differences for the bubble measures between markets 1-3 and markets 10-12 (see the last line in Figure 3). The differences between markets 1-3 and markets 4-6 or between markets 4-6 and markets 10-12 are not significant. Since we are interested in bubbles, we carried out the same analysis but after excluding periods 1-5, as mentioned before. Note that in these periods the market price is generally below the fundamental value, probably because participants get used to the trading in these periods. In Table $\mathrm{A} 1$ in Appendix B we reproduce Table 3 after excluding periods 1-5. Now, all bubble/mispricing measures reveal a significant difference at the $5 \%$ significance level between markets 1-3 and markets 10-12. As before, we do not see a significant difference between markets 1-3 and markets 4-6 and between markets 4-6 and markets 10-12. Therefore, significant differences materialize only when comparing the extremes. For turnover, no significant difference can be documented.

One may wonder whether these findings are robust to which markets we compare. 
What if we compare the first 4 or 5 markets to the last 4 or 5 markets? If we repeat the same exercise but compare the upper 4/5 markets with the lower 4/5 markets (and ignore markets 7 and 9, which do not show the crash pattern), then we do not observe any significant differences in the bubble/mispricing measures. It is not surprising because as we widen the scope and include more markets from the middle, the differences between the groups of markets become less distinguished. If we carry out the same exercise after excluding periods 1-5, then when comparing the upper and lower 4/5 markets, we see a significant difference at $5 \%$ for total dispersion and amplitude.

If we calculate the correlation between the bubble/mispricing measures and the marketlevel individual characteristics (see Table A3 in Appendix (C), only few significant associations emerge. The mean of risk tolerance has the expected positive sign for all bubble/mispricing measures but exhibits only marginal positive significance with only one of the bubble measures (positive amplitude)10 The lack of systemic correlations suggests that generally there is no linear relationship between bubble/mispricing measures and individual characteristics aggregated on the market level. In Appendix D we present the results of some simple OLS regressions in which the dependent variables are the bubble/mispricing measures, while the explanatory variables are the market-level individual characteristics. These simple linear regressions reflect what we have seen with the correlations. Hence, risk is only marginally significant when explaining positive amplitude. Both the mean and the standard deviation of risk tolerance increases $R^{2}$ sometimes markedly, but none of these variables becomes significant 11 We summarize these observations in Finding 1.

Finding 1: There is no linear relationship between risk tolerance and bubble/mispricing measures. However, if we compare markets pertaining to the upper and lower quartiles for all the periods, then we observe significant differences at the $5 \%$ significance level for the bubble measures. If we exclude periods 1-5, then the differences are significant at $5 \%$ for all bubble and mispricing measures.

The previous finding lends support to our Hypothesis 1.

\footnotetext{
${ }^{10}$ The mean of uncertainty is weakly correlated with average bias, while the mean of cognitive abilities is negatively associated in a significant manner with two mispricing measures. The share of female participants is negatively correlated with turnover.

${ }^{11}$ In the regression explaining positive amplitude, the mean of risk tolerance remains marginally significant.
} 
Figure 2: Excess buy orders as a function of risk, cognitive abilities, and gender

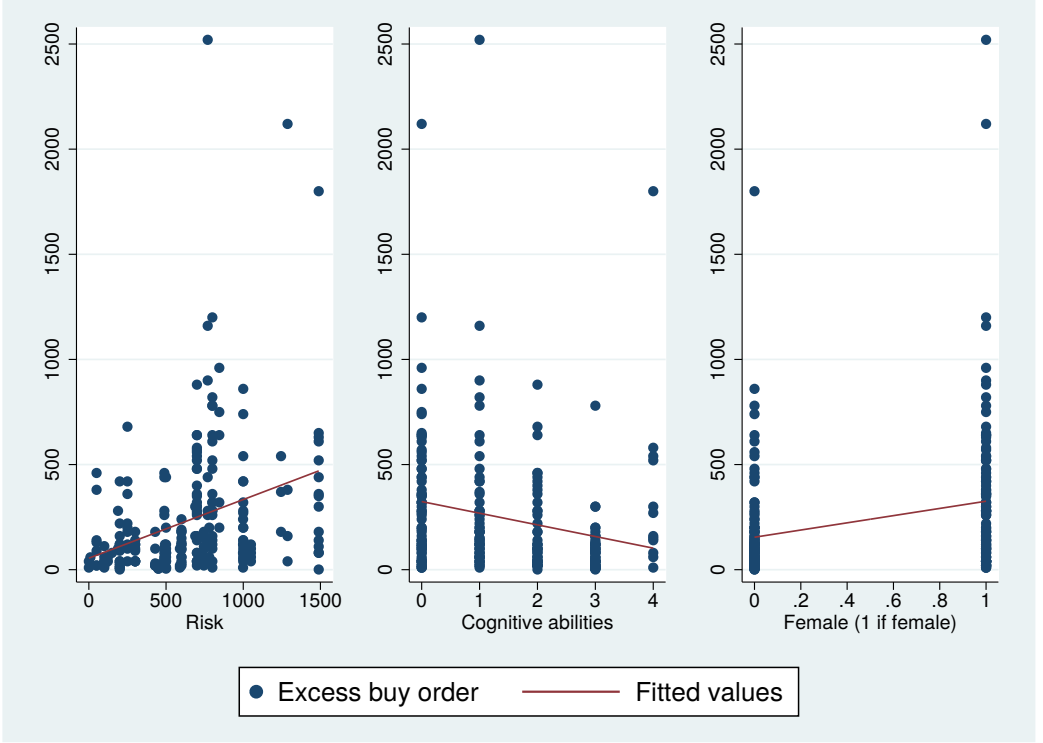

\subsection{Individual buy and sell orders}

As conjectured earlier, we expect that the more risk-tolerant the trader, the more she values a risky asset. This higher valuation may materialize in a higher buy order because if a trader attaches a higher value to owning an asset, then she might be willing to pay a higher price. By the same token, if a more risk-tolerant trader values an asset more, then she may be willing to sell it only at higher prices. Higher buy and sell orders may induce higher prices that may lead to a bubble. The previous reasoning implies that the process is more likely to occur in markets formed by more risk tolerant traders. Therefore, risk sorting may enhance bubbles.

Bubbles emerge if the market price exceeds the fundamental value, and the larger is this excess, the more likely that eventually a bubble forms. Therefore, here we attempt to explain the difference between the buy order and the fundamental value (excess buy order) and the difference between the sell order and the fundamental value (excess sell order) by using individual and market-level characteristics. We also account for the periods, financial position, and experience that participants have. Figures 2 and 3 suggest that risk aversion, cognitive abilities, and gender may have an impact on how much buy and 
Figure 3: Excess sell orders as a function of risk, cognitive abilities, and gender

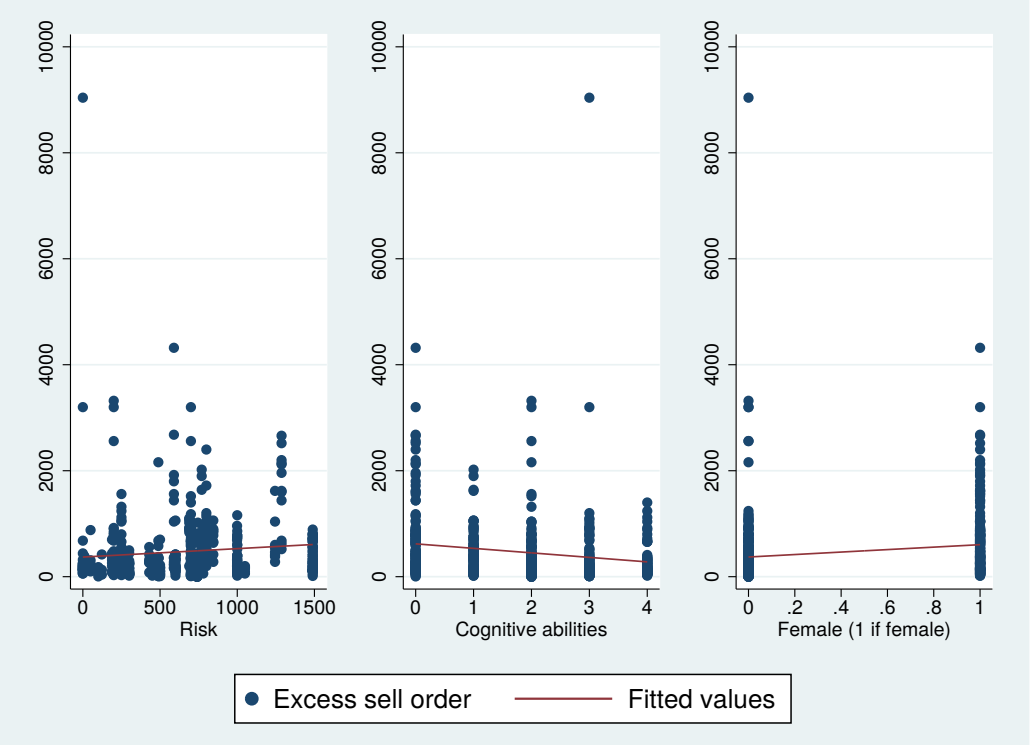

sell orders exceed the fundamental value. A point corresponds to a buy/sell order that exceeds the fundamental value submitted in round 1 of the experiment in any period by a trader of a given risk tolerance/cognitive ability/gender. The figures also suggest that the effect seems to be stronger for buy orders.

According to the graph, more risk-tolerant/cognitively-less-able participants tend to submit buy/sell orders that increasingly exceed the fundamental value. Our data suggest that females are more likely to submit excessive buy/sell orders. To see if these and other factors really matter, we carry out a regression analysis that controls for the when a buy/sell order is placed among list of other variables (as before, we exclude markets 7 and 9 from this analysis). We also include the lag of market price and dividend (that is, the market price and dividend in the last period) in the regression, as these represent the most recent market experience of the participants. To account for the participants' financial position, we also consider their asset and cash holding. Since we are mainly interested in the effect of time-invariant variables, we use a random-effects panel estimation. Standard errors are clustered on the individual level.

On the individual level, risk and uncertainty are positively and significantly correlated, hence, in the regressions we use only the risk aversion measure. Cognitive abilities correlate negatively in a significant way with being female. As both these measures have been found important in the literature, we will use both of them in separate regressions. Hence, our individual characteristics are risk tolerance (the variable used to form the groups), cognitive abilities measured by the Cognitive Reflection Test, a dummy variable that is 
1 if a participant chooses the risky option in the stag hunt game (strategic uncertainty), and a dummy for being female.

Table 4: Excess buy order: Random-effects panel regressions with individual characteristics

\begin{tabular}{|c|c|c|c|c|c|}
\hline & (1) & $(2)$ & $(3)$ & $(4)$ & $(5)$ \\
\hline Variables & \multicolumn{5}{|c|}{ Dependent variable: Excess buy order } \\
\hline Risk Tolerance & $\begin{array}{c}0.205^{* * *} \\
(0.0612)\end{array}$ & & & & $\begin{array}{c}0.139^{* *} \\
(0.0547)\end{array}$ \\
\hline Cognitive Abilities & & $\begin{array}{c}-58.77^{* * *} \\
(16.45)\end{array}$ & & & $\begin{array}{c}-37.15^{* * *} \\
(10.92)\end{array}$ \\
\hline Female & & & $\begin{array}{l}137.3^{* * *} \\
(46.09)\end{array}$ & & $\begin{array}{l}101.2^{* * *} \\
(37.35)\end{array}$ \\
\hline Strategic Uncertainty & & & & $\begin{array}{l}-2.895 \\
(55.10)\end{array}$ & $\begin{array}{r}2.052 \\
(48.10)\end{array}$ \\
\hline Assets (lagged) & $\begin{array}{c}-24.77^{* *} \\
(12.47)\end{array}$ & $\begin{array}{c}-19.71^{*} \\
(11.35)\end{array}$ & $\begin{array}{c}-15.43 \\
(11.83)\end{array}$ & $\begin{array}{c}-15.38 \\
(12.52)\end{array}$ & $\begin{array}{c}-24.51^{* *} \\
(11.36)\end{array}$ \\
\hline Cash (lagged) & $\begin{array}{c}-0.0265^{* *} \\
(0.0115)\end{array}$ & $\begin{array}{c}-0.0268^{* * *} \\
(0.00934)\end{array}$ & $\begin{array}{r}-0.0200^{* *} \\
(0.00897)\end{array}$ & $\begin{array}{c}-0.0265^{* *} \\
(0.0122)\end{array}$ & $\begin{array}{r}-0.0219^{* *} \\
(0.00923)\end{array}$ \\
\hline Market Price (lagged) & $\begin{array}{l}0.447^{* * *} \\
(0.115)\end{array}$ & $\begin{array}{l}0.497^{\text {*** }} \\
(0.104)\end{array}$ & $\begin{array}{l}0.460^{* * *} \\
(0.109)\end{array}$ & $\begin{array}{l}0.542^{* * *} \\
(0.108)\end{array}$ & $\begin{array}{l}0.389^{* * *} \\
(0.101)\end{array}$ \\
\hline Dividend (lagged) & $\begin{array}{c}-0.126 \\
(0.173)\end{array}$ & $\begin{array}{c}-0.158 \\
(0.175)\end{array}$ & $\begin{array}{r}-0.0901 \\
(0.175)\end{array}$ & $\begin{array}{c}-0.0974 \\
(0.172)\end{array}$ & $\begin{array}{r}-0.149 \\
(0.165)\end{array}$ \\
\hline Remaining Period & $\begin{array}{c}-78.57^{* * *} \\
(28.10)\end{array}$ & $\begin{array}{c}-93.69^{* * *} \\
(29.10)\end{array}$ & $\begin{array}{c}-84.96^{* * *} \\
(28.55)\end{array}$ & $\begin{array}{c}-96.27^{* * *} \\
(27.52)\end{array}$ & $\begin{array}{c}-74.33^{* * *} \\
(27.52)\end{array}$ \\
\hline Remaining Period Squared & $\begin{array}{c}2.930 \\
(1.893)\end{array}$ & $\begin{array}{c}3.715^{*} \\
(1.951)\end{array}$ & $\begin{array}{c}3.632^{*} \\
(1.933)\end{array}$ & $\begin{array}{c}3.807^{* *} \\
(1.895)\end{array}$ & $\begin{array}{c}3.027 \\
(1.869)\end{array}$ \\
\hline Constant & $\begin{array}{c}126.1 \\
(106.0) \\
\end{array}$ & $\begin{array}{l}348.4^{* * *} \\
(122.2) \\
\end{array}$ & $\begin{array}{l}137.9 \\
(92.84) \\
\end{array}$ & $\begin{array}{c}207.7 \\
(139.4) \\
\end{array}$ & $\begin{array}{l}190.8^{*} \\
(115.7) \\
\end{array}$ \\
\hline Observations & 211 & 211 & 211 & 211 & 211 \\
\hline Prob $>\chi^{2}$ & $7.49 e-07$ & $2.73 e-08$ & $3.78 e-06$ & $6 \quad 9.42 e-05$ & 50 \\
\hline
\end{tabular}

As can be seen in Table 4, when considering individual characteristics, risk tolerance, cognitive abilities and gender significantly affect (at 1\% significance level) how much buy orders exceed the fundamental value, even if we take into account a host of variables that reflect financial position and market experience. More risk-tolerant individuals tend to submit more excessive buy orders. In line with the findings in Bosch-Rosa et al. (2018), traders with better cognitive abilities submit less excessive buy orders, lowering the chance that a bubble forms. Our data indicate that females were more likely to submit excessive buy orders, contrary to what we would expect based on Eckel and Füllbrunn (2015). Note that Wang et al. (2017) show that the effect of gender may be sensitive to culture, as in China all-female groups do not generate smaller bubbles than all-male groups. According to the regressions, strategic uncertainty captured by the choice in the stag hunt game does not seem to influence the excess buy order. When we plug all these individual characteristics in the same regression, then the magnitudes change somewhat (due to 
the correlation between the variables), but the sign and the significance remain. The fact that risk tolerance remains significant in the last column even after controlling for cognitive abilities and gender indicates that risk tolerance has an additional effect and is an important factor to understand how bubbles emerge. The coefficient of the variable Remaining Period is consistently negative and significant. Note that fundamental value decreases with the number of periods, so the same excess buy order (that is, buy order minus fundamental value) is relatively smaller at the beginning of the round than at the end, when the fundamental value goes to zero. Hence, the negative coefficient indicates that even if the buy order exceeds the fundamental value, it does so in a diminishing manner over time.

The financial position is relevant, as both the number of assets and cash holding at the end of the previous period decrease the excess in the buy orders significantly, and the effect of cash seems to be stronger. This suggests that those who had many assets and/or cash were not desperate to buy new assets and did not tend to submit excessive buy orders. Market price in the previous period had a positive and significant effect on excess buy orders: The higher the market price is, the larger the excess in the buy order. The amount of dividend in the previous period has no such effect.

Table A11 in Appendix E shows the results of the same regression when the dependent variable is excess sell order. There none of the individual characteristics proves to be significant, while the rest of the variables behaves as in Table 4. This suggests that buy orders contribute more to the formation of bubbles. If instead of excess buy/sell orders we only use buy/sell orders, then we fail to find any significant effect of the individual characteristics, while the rest of the variables has qualitatively the same effect.

As a robustness check, we carry out the same analysis but with the dependent variable being relative excess buy/sell order. Relative excess buy/sell order is excess buy/sell order divided by the fundamental value in a given period. Table A13 in Appendix F contains the results for relative excess buy orders. When introducing the individual characteristics separately, we see the same effects as in Table 4. However, when introducing all individual characteristics jointly, the effect of risk tolerance remains positive, but it is not significant any more. The effect of cognitive ability and gender has the same sign as before, moreover, they are significant both when considered separately and jointly. The effect of financial position ceases to be significant, but the lagged market price has the same significant effect as before. Dividend has no significant effect as in Table 4. Table A14 
in Appendix $\mathrm{F}$ shows the findings for relative excess sell orders. When considering the individual characteristics separately, only risk tolerance has a significant effect (at 10\%) with the expected sign. However, when considering the individual characteristics jointly, the significance disappears. In these regressions financial position has some importance, as the effect of the assets is significant and has the same sign as in Table A11. We observe that cash and dividend have no effect, while lagged market price has a positive and significant effect.

As a further check, we consider market-level characteristics instead of individual characteristics. Remember that the idea of the paper is that if we sort individuals according to risk tolerance into markets, then it may affect the emergence of bubbles. Hence, we may expect to see larger excess buy/sell orders on markets with a higher average risk tolerance 12 Table 5 contains the same regressions as Table 4 but with the average and standard deviation of market-level characteristics (whenever possible). Reassuringly, the averages of risk, cognitive abilities, and gender are again significant and have the same sign. Hence, the more risk-tolerant a market is on average, the higher the individual excess buy orders. Similarly, markets with a higher average cognitive ability have less excess buy orders, and in markets with a higher share of females, we see higher excess buy orders. Strategic uncertainty proves insignificant in these regressions as well. The standard deviation of risk tolerance does not seem to affect excess buy orders. However, a higher variability in cognitive abilities leads to higher excess buy orders. This is in line with Hanaki et al. (2017). When pooling all the market-level variables, some of the significance vanishes, but risk and gender remain significant. The variables reflecting financial position and market experience are similar in value, sign, and significance to those in Table 4 ,

The corresponding regressions for excess sell orders can be found in Table A12 in Appendix E. Neither the average nor the standard deviation of risk tolerance on the market level affects excess sell orders. The standard deviation of cognitive abilities (but not the average) has a significant positive effect, while being female-as in previous regressionsincreases excess sell order, ceteris paribus. Strategic uncertainty on the market level is not significant. When pooling the characteristics, only cognitive abilities have a significant effect, decreasing excess sell orders. In these regressions the effect of the financial position

\footnotetext{
${ }^{12}$ We do not have individual and market-level characteristics in the same regressions because they correlate significantly in case of risk, cognitive abilities, and gender.
} 
Table 5: Excess buy orders: Random-effects panel regressions with market-level characteristics

\begin{tabular}{|c|c|c|c|c|c|}
\hline & (1) & $(2)$ & $(3)$ & $(4)$ & $(5)$ \\
\hline Variables & \multicolumn{5}{|c|}{ Dependent variable: Excess buy order } \\
\hline Risk Tol. Average & $\begin{array}{c}0.220^{* * *} \\
(0.0641)\end{array}$ & & & & $\begin{array}{c}0.136^{* *} \\
(0.0562)\end{array}$ \\
\hline Risk Tol. St.Dev. & $\begin{array}{c}-0.336 \\
(0.668)\end{array}$ & & & & $\begin{array}{l}1.619 \\
(1.295)\end{array}$ \\
\hline Cognitive Average & & $\begin{array}{c}-82.99^{* *} \\
(41.72)\end{array}$ & & & $\begin{array}{c}-73.25 \\
(57.47)\end{array}$ \\
\hline Cognitive St.Dev. & & $\begin{array}{l}212.0^{* * *} \\
(72.24)\end{array}$ & & & $\begin{array}{l}51.00 \\
(84.19)\end{array}$ \\
\hline Share of Females & & & $\begin{array}{l}37.64^{* * *} \\
(12.17)\end{array}$ & & $\begin{array}{c}41.94^{* *} \\
(19.82)\end{array}$ \\
\hline Str.Uncertainty Average & & & & $\begin{array}{c}167.8 \\
(129.7)\end{array}$ & $\begin{array}{c}-264.4 \\
(181.5)\end{array}$ \\
\hline Assets (lagged) & $\begin{array}{c}-23.99^{*} \\
(12.41)\end{array}$ & $\begin{array}{c}-23.88^{*} \\
(12.78)\end{array}$ & $\begin{array}{c}-18.30 \\
(12.89)\end{array}$ & $\begin{array}{c}-17.79 \\
(12.38)\end{array}$ & $\begin{array}{c}-30.14^{* *} \\
(12.22)\end{array}$ \\
\hline Cash (lagged) & $\begin{array}{c}-0.0263^{* *} \\
(0.0116)\end{array}$ & $\begin{array}{c}-0.0269^{* *} \\
(0.0121)\end{array}$ & $\begin{array}{c}-0.0268^{* *} \\
(0.0118)\end{array}$ & $\begin{array}{c}-0.0267^{* *} \\
(0.0112)\end{array}$ & $\begin{array}{c}-0.0295^{* *} \\
(0.0130)\end{array}$ \\
\hline Market Price (lagged) & $\begin{array}{l}0.428^{* * *} \\
(0.109)\end{array}$ & $\begin{array}{l}0.413^{* * *} \\
(0.110)\end{array}$ & $\begin{array}{l}0.365^{* * *} \\
(0.107)\end{array}$ & $\begin{array}{l}0.529^{* * *} \\
(0.115)\end{array}$ & $\begin{array}{l}0.248^{* *} \\
(0.112)\end{array}$ \\
\hline Dividend (lagged) & $\begin{array}{c}-0.118 \\
(0.176)\end{array}$ & $\begin{array}{c}-0.248 \\
(0.185)\end{array}$ & $\begin{array}{c}-0.108 \\
(0.173)\end{array}$ & $\begin{array}{c}-0.123 \\
(0.183)\end{array}$ & $\begin{array}{c}-0.202 \\
(0.186)\end{array}$ \\
\hline Remaining Period & $\begin{array}{c}-74.88^{* * *} \\
(27.86)\end{array}$ & $\begin{array}{c}-59.72^{* *} \\
(28.06)\end{array}$ & $\begin{array}{c}-64.98^{* *} \\
(27.19)\end{array}$ & $\begin{array}{c}-85.85^{* * *} \\
(29.21)\end{array}$ & $\begin{array}{c}-47.74^{*} \\
(27.75)\end{array}$ \\
\hline Remaining Period Squared & $\begin{array}{c}2.735 \\
(1.870)\end{array}$ & $\begin{array}{c}1.581 \\
(1.946)\end{array}$ & $\begin{array}{c}2.521 \\
(1.806)\end{array}$ & $\begin{array}{c}3.004 \\
(2.049)\end{array}$ & $\begin{array}{c}1.726 \\
(1.850)\end{array}$ \\
\hline Constant & $\begin{array}{c}131.9 \\
(106.1)\end{array}$ & $\begin{array}{c}138.9 \\
(160.9)\end{array}$ & $\begin{array}{c}153.2 \\
(114.2)\end{array}$ & $\begin{array}{c}107.2 \\
(113.4)\end{array}$ & $\begin{array}{c}303.0 \\
(261.2)\end{array}$ \\
\hline Observations & 211 & 211 & 211 & 211 & 211 \\
\hline Prob $>\chi^{2}$ & $5.17 e-07$ & $3.21 e-06$ & $65.76 e-05$ & $5 \quad 3.27 e-05$ & 50 \\
\hline
\end{tabular}

Robust standard errors in parentheses; ${ }^{* * *} \mathrm{p}<0.01,{ }^{* *} \mathrm{p}<0.05,{ }^{*} \mathrm{p}<0.1$

and market experience is somewhat weaker, but when significant, they have the same sign as before.

Finding 2: We find convincing evidence that risk tolerance plays an important role in explaining how much individual buy orders exceed the fundamental value, while the evidence is weaker when sell orders are considered. In line with the existing literature, we find that cognitive abilities and gender are important factors in understanding excess buy orders. Interestingly, the effects of risk tolerance, cognitive abilities, and gender are weaker or non-existent when investigating excess sell orders. Financial position is often important: More assets and/or more cash lead to less excess buy/sell orders. Higher market prices in the last period consistently increase both excess buy and sell orders, while dividend does not have an influence on excess buy/sell orders. 


\subsection{Round 2}

A general finding in the literature (see Palan, 2013 or Powell and Shestakova, 2016) is that experience decreases bubbles/mispricing. Therefore, in later rounds generally smaller or no bubbles are observed. Reassuringly, we observe such tendencies when studying the price evolution in round 2 (see Appendix G). More precisely, in markets 1-3 we do not see a decrease in bubbles/mispricing, however, in markets 4-6 and markets 10-12, mispricing vanishes and per-period prices track the fundamental value very closely. Markets 7 and 9 behave as strangely as they do in round 1, while in the case of market 8 mispricing disappears.

To check if there are still significant differences between markets 1-3 with the most risk-tolerant traders and markets 10-12 with the most risk averse ones, we carry out the Mann-Whitney test (see Appendix $\underline{\mathrm{H}}$ ). When considering all periods, in two of the three bubble measures (Positive Deviation and Positive Amplitude), we still observe significant differences and one of the mispricing measures (Total Dispersion) also exhibits significant differences. When excluding periods 1-5, there are significant differences at $5 \%$ significance level in all bubble/mispricing measures except boom duration and turnover, just as in round 1 .

When we apply the Mann-Whitney test to compare round 1 and round 2 bubble measures across the market quartiles (see Table A16 Appendix II), we observe that in markets 1-3 bubble/mispricing measure did not diminish. Participants in these markets in round 2 generated similar bubbles as in round 1. However, in markets 4-6 in all mispricing measures and in turnover we see a significant decrease at the $5 \%$ significance levels but no significant decrease is observed in the bubble measures. In markets 7-9 there is no noticeable decrease in the bubble measures across rounds, while in markets 10-12 we observe significant decline in two mispricing measures. In these last two cases the lack of significant decrease is not surprising, as in round 1 there were already no pronounced bubbles/mispricings.

Finding 3: Significant differences remain between the three markets with the most and least risk-tolerant traders when considering several bubble/mispricing measures. Moreover, bubbles and mispricing remains in the markets with the most risk-tolerant traders, while they diminish or disappear in other markets that exhibit the crash pattern.

Finding 3 suggests that there is some persistence of bubbles and mispricing when 
considering the markets populated by the most risk-tolerant traders.

\section{Conclusion}

Recent studies indicate that sorting in markets along some individual characteristics may be behind the emergence of bubbles in experimental asset markets. We claim that there is some sorting according to risk tolerance going on in real life and investigate in the lab whether such sorting may explain the formation of bubbles.

We find evidence that markets with the most risk-tolerant traders exhibit larger bubbles/mispricing than those with the least risk-tolerant ones. However, the effect is not linear, as we were able to document significant differences only on the extremes. We also find some convincing evidence that more risk-tolerant traders are more likely to submit buy orders that exceed the fundamental value of the asset. Since more risk-tolerant traders participated in the same markets, these excess buy orders may be a prime drive behind market prices over the fundamental value. Interestingly, we do not see this mechanism at work to this extent when studying sell orders. We also document that bubbles/mispricing is persistent in the markets populated by the most risk-tolerant traders.

\section{Acknowledgment}

This work was supported by the Higher Education Institutional Excellence Program of the Ministry of Human Capacities in the framework of the 'Financial and Retail Services' research project (20764-3/2018/FEKUTSTRAT) at the Corvinus University of Budapest; by the SME under research project ECO2014-52372; and by the Hungarian National Research, Development and Innovation Office, grant numbers K124550, K119683 and K109354. 


\section{References}

Akiyama, E., N. Hanaki, and R. Ishikawa (2017). It is not just confusion! strategic uncertainty in an experimental asset market. The Economic Journal 127(605), F563F580.

Andersson, O., H. J. Holm, J.-R. Tyran, and E. Wengström (2016). Risk aversion relates to cognitive ability: Preferences or noise? Journal of the European Economic Association 14(5), 1129-1154.

Benjamin, D. J., S. A. Brown, and J. M. Shapiro (2013). Who is 'behavioral'? cognitive ability and anomalous preferences. Journal of the European Economic Association 11(6), 1231-1255.

Bosch-Rosa, C., T. Meissner, and A. Bosch-Domènech (2018). Cognitive bubbles. Experimental Economics 21(1), 132-153.

Breaban, A. and C. N. Noussair (2015). Trader characteristics and fundamental value trajectories in an asset market experiment. Journal of Behavioral and Experimental Finance 8, 1-17.

Burks, S. V., J. P. Carpenter, L. Goette, and A. Rustichini (2009). Cognitive skills affect economic preferences, strategic behavior, and job attachment. Proceedings of the National Academy of Sciences 106(19), 7745-7750.

Crosetto, P. and A. Filippin (2013). The bomb risk elicitation task. Journal of Risk and Uncertainty 47(1), 31-65.

Croson, R. and U. Gneezy (2009). Gender differences in preferences. Journal of Economic Literature $47(2), 448-74$.

Cueva, C. and A. Rustichini (2015). Is financial instability male-driven? gender and cognitive skills in experimental asset markets. Journal of Economic Behavior \& Organization 119, 330-344.

Dohmen, T., A. Falk, D. Huffman, and U. Sunde (2010). Are risk aversion and impatience related to cognitive ability? American Economic Review $100(3), 1238-60$. 
Dohmen, T., A. Falk, D. Huffman, and U. Sunde (2018). On the relationship between cognitive ability and risk preference. Journal of Economic Perspectives 32(2), 115-34.

Dufwenberg, M., T. Lindqvist, and E. Moore (2005). Bubbles and experience: An experiment. American Economic Review 95(5), 1731-1737.

Eckel, C. C. and S. C. Füllbrunn (2015). Thar she blows? gender, competition, and bubbles in experimental asset markets. American Economic Review 105(2), 906-920.

Eckel, C. C. and S. C. Füllbrunn (2017). Hidden vs. known gender effects in experimental asset markets. Economics Letters 156, 7-9.

Eckel, C. C. and P. J. Grossman (2008). Men, women and risk aversion: Experimental evidence. In C. Plott and V. Smith (Eds.), Handbook of Experimental Economics Results, Chapter 113, pp. 1061-1073. New York: Elsevier.

El-Sehity, T., H. Haumer, C. Helmenstein, E. Kirchler, and B. Maciejovsky (2002). Hindsight bias and individual risk attitude within the context of experimental asset markets. Journal of Psychology and Financial Markets 3(4), 227-235.

European Parliament (2014). On Markets in Financial Instruments and Amending Directive 2002/92/EC and Directive 2011/61/EU . (EP Directive 2014/65/EU).

European Parliament (2016). On Insurance Distribution. (EP Directive 2016/97/EU).

Fellner, G. and B. Maciejovsky (2007). Risk attitude and market behavior: Evidence from experimental asset markets. Journal of Economic Psychology 28(3), 338-350.

Filippin, A. and P. Crosetto (2016). A reconsideration of gender differences in risk attitudes. Management Science 62(11), 3138-3160.

Fischbacher, U. (2007). z-tree: Zurich toolbox for ready-made economic experiments. Experimental Economics 10(2), 171-178.

Fossen, F. (2012). Risk attitudes and private business equity. In D. Cummings (Ed.), The Oxford Handbook of Entrepreneurial Finance. New York: Oxford University Press.

Frederick, S. (2005). Cognitive reflection and decision making. Journal of Economic Perspectives 19(4), 25-42. 
Green, C., J. N., and T. Y. (2009). Gender and job performance: Evidence from wall street. Financial Analysts Journal 65(6), 65-78.

Hanaki, N., E. Akiyama, Y. Funaki, R. Ishikawa, et al. (2017). Diversity in cognitive ability enlarges mispricing in experimental asset markets. Technical report, Groupe de REcherche en Droit, Economie, Gestion (GREDEG CNRS), University of Nice Sophia Antipolis.

Hanaki, N., E. Akiyama, and R. Ishikawa (2018a). Behavioral uncertainty and the dynamics of traders confidence in their price forecasts. Journal of Economic Dynamics and Control 88, 121-136.

Hanaki, N., E. Akiyama, and R. Ishikawa (2018b). Effects of different ways of incentivizing price forecasts on market dynamics and individual decisions in asset market experiments. Journal of Economic Dynamics and Control 88, 51-69.

Haruvy, E., Y. Lahav, and C. N. Noussair (2007). Traders' expectations in asset markets: Experimental evidence. American Economic Review 97(5), 1901-1920.

Holt, C. A., M. Porzio, and M. Y. Song (2017). Price bubbles, gender, and expectations in experimental asset markets. European Economic Review 100, 72-94.

Horn, D. and H. J. Kiss (2018). Which preferences associate with school performance? Lessons from an exploratory study with university students. PloS one 13(2), e0190163.

Janssen, D. (2017). Birds of a Feather: Price Dynamics and Trading Behavior in Composed Markets. Ph. D. thesis, [Sl: sn].

Janssen, D.-J., S. Füllbrunn, and U. Weitzel (2018). Individual speculative behavior and overpricing in experimental asset markets. Experimental Economics, 1-23.

King, R. R. (1991). Private information acquisition in experimental markets prone to bubble and crash. Journal of Financial Research 14(3), 197-206.

King, R. R., V. L. Smith, A. W. Williams, and M. V. van Boening (1993). The robustness of bubbles and crashes in experimental stock markets. In R. H. Day and P. Chen (Eds.), Nonlinear Dynamics and Evolutionary Economics. New York: Oxford University Press. 
Kirchler, E. and B. Maciejovsky (2002). Simultaneous over- and underconfidence: Evidence from experimental asset markets. Journal of Risk and Uncertainty 25(1), 65-85.

Kirchler, E., B. Maciejovsky, and M. Weber (2005). Framing effects, selective information, and market behavior: An experimental analysis. Journal of Behavioral Finance 6(2), 90-100.

Kocher, M. G., K. E. Lucks, and D. Schindler (2018). Unleashing animal spirits: Selfcontrol and overpricing in experimental asset markets. The Review of Financial Studies, hhy109.

Lazear, E. P. and K. L. Shaw (2007, November). Personnel economics: The economist's view of human resources. Working Paper 13653, National Bureau of Economic Research.

Lei, V., C. N. Noussair, and C. R. Plott (2001). Nonspeculative bubbles in experimental asset markets: Lack of common knowledge of rationality vs. actual irrationality. Econometrica 69(4), 831-859.

Lei, V. and F. Vesely (2009). Market efficiency: Evidence from a no-bubble asset market experiment. Pacific Economic Review 14(2), 246-258.

Maciejovsky, B., E. Kirchler, and H. Schwarzenberger (2007). Misperception of chance and loss repair: On the dynamics of tax compliance. Journal of Economic Psychology 28(6), $678-691$.

Miller, R. M. (2002). Can markets learn to avoid bubbles? Journal of Psychology and Financial Markets 3(1), 44-52.

Noussair, C. N. and O. Powell (2010). Peaks and valleys: Price discovery in experimental asset markets with non-monotonic fundamentals. Journal of Economic Studies 37(2), $152-180$.

Oechssler, J., C. Schmidt, and W. Schnedler (2011). On the ingredients for bubble formation: Informed traders and communication. Journal of Economic Dynamics and Control 35(11), 1831-1851.

Palan, S. (2013). A review of bubbles and crashes in experimental asset markets. Journal of Economic Surveys 27(3), 570-588. 
Palan, S. (2015). Gims-software for asset market experiments. Journal of Behavioral and Experimental Finance 5, 1-14.

Porter, D. P. and V. L. Smith (1995). Futures contracting and dividend uncertainty in experimental asset markets. The Journal of Business 68(4), 509-541.

Porter, D. P. and V. L. Smith (2008). Price bubbles. In C. Plott and V. Smith (Eds.), Handbook of Experimental Economics Results, Chapter 30, pp. 247-255. Amsterdam: North Holland.

Powell, O. and N. Shestakova (2016). Experimental asset markets: A survey of recent developments. Journal of Behavioral and Experimental Finance 12, 14-22.

Sapienza, P., L. Zingales, and D. Maestripieri (2009). Gender differences in financial risk aversion and career choices are affected by testosterone. Proceedings of the National Academy of Sciences 106(36), 15268-15273.

Smith, V. L., G. L. Suchanek, and A. W. Williams (1988). Bubbles, crashes, and endogenous expectations in experimental spot asset markets. Econometrica 56(5), 1119-1151.

Stöckl, T., J. Huber, and M. Kirchler (2010, Sep). Bubble measures in experimental asset markets. Experimental Economics 13(3), 284-298.

van Boening, M. V., A. W. Williams, and S. LaMaster (1993). Price bubbles and crashes in experimental call markets. Economics Letters 41(2), 179-185.

Wang, J., D. Houser, H. Xu, et al. (2017). Do females always generate small bubbles? experimental evidence from us and china. Technical report. 


\section{A Appendix A: Instructions}

Dear Participant,

Thank you for participating in this experiment! Participation is VOLUNTARY and ANONYMOUS, that is, none of the participants will ever get any information about your decisions or earnings. We treat all information that we gather during the experiment confidentially.

Please, follow the instructions carefully. Always keep the identifier that you received at the entrance with you, as you need it during the experiment and to get your earnings at the end. Should you have questions, raise your hand and we will attend to you. During the experiment it is forbidden to speak or communicate in any other way with the rest of the participants. If you do not comply with that rule, then you will be excluded from the experiment. Please, switch off your mobile phone.

\section{The course of the experiment}

1.a Tasks

1.b Trial period

1.c Questionnaire

- Reassignment to other computer-

2 Trading game

3 Payment of earnings

You receive 1000 HUFs for participating in this experiment, and for your performance in 1.a and 2 you are entitled to additional earnings. During the experiment the experimental currency is called petak; We register all your transactions in this currency. We pay all the petaks that you earn at the end of the experiment in cash at the following exchange rate: 3 petaks $=\mathbf{1} \mathbf{H U F}$.

\section{Part 1}

In part 1.a you see four tasks and the answers you give in those tasks may earn you money. Note that the questions you see in these tasks often have no objectively correct 
answer. At the end of the experiment we choose one of the tasks randomly to calculate your earnings and your earnings in part 1 is determined by the answer that you have given in that task.

In part 1.b we go through how the trading game works and then, you play a trial period. The trial period is followed by a short questionnaire (1.c). Then, we regroup you and you may have to change rooms.

\section{Part 2}

In part 2 you play the trading game in groups of 8 . In the trading game you may sell and buy securities. If you make good decisions, then you may earn a substantial amount of money. This part of the experiment consists of two rounds that are independent, and in each round there will be 15 periods. You will receive more information about the trading game before the trial period.

\section{Market and Trading}

You trade on a market with 7 other participants. Throughout the experiment the markets do not change, that is, you trade with the same participants.

The experiment consists of 2 independent rounds, and in each round you can trade for 15 periods. At the beginning of each round the participants are endowed with certain amount of ECU (experimental currency) and some assets. The amount of ECUs and the number of assets may vary among participants, but the expected value of the bundle of ECUs and assets someone receives is the same for all participants.

Assets expire after 15 periods, that is, at the end of the round they are worthless. If you buy an asset, then you will own the asset starting from the period you buy it until you sell it. After each period (including the last one, i.e. 15th period) each asset yields 0, 40, 140, or 300 ECUs. The probability of each dividend is $25 \%$. This means that the average dividend in each period is 120 ECUs. The dividend is added to your account automatically after each period. After the dividends are distributed at the end of 15th period, the market closes and the assets cease to exist.

We attach a table named "Average value of holding an asset," which can help you in deciding whether to buy or sell. The table shows, how much dividend you can expect on average if you keep the asset till the end of the round. We calculated this value by 
taking the remaining number of periods and multiplying it 120, the average dividend in each period.

If you want to buy an asset, then you can place a buy order to do so. A buy order consists of the number of assets you want to buy and the highest price you are willing to pay for each asset. It is important to note that you will buy each asset for the same price.

If you want to sell an asset, then you can place a sell order to do so. Similarly to the buy order, a sell order consists of the amount of asset you want to sell and the lowest price for which you are willing to sell each asset. As in the previous case, each asset will be sold for the same price.

It is important to note that you can place only one sell order in each period, that is, you can only sell your assets for one price. You can sell more than one asset for this price (but only as many as you own). Similarly, you can place only one buy order, but for this price you can buy more than one asset (provided you have enough ECUs). You can place both a buy and a sell order in one period, but in this case the buying price must be lower than the selling price. In all cases prices refer to per-asset prices. You are not obliged to trade. If you think that neither selling nor buying an asset is worth it, then you do not need to initiate any transaction.

Figure 4: Trading screen

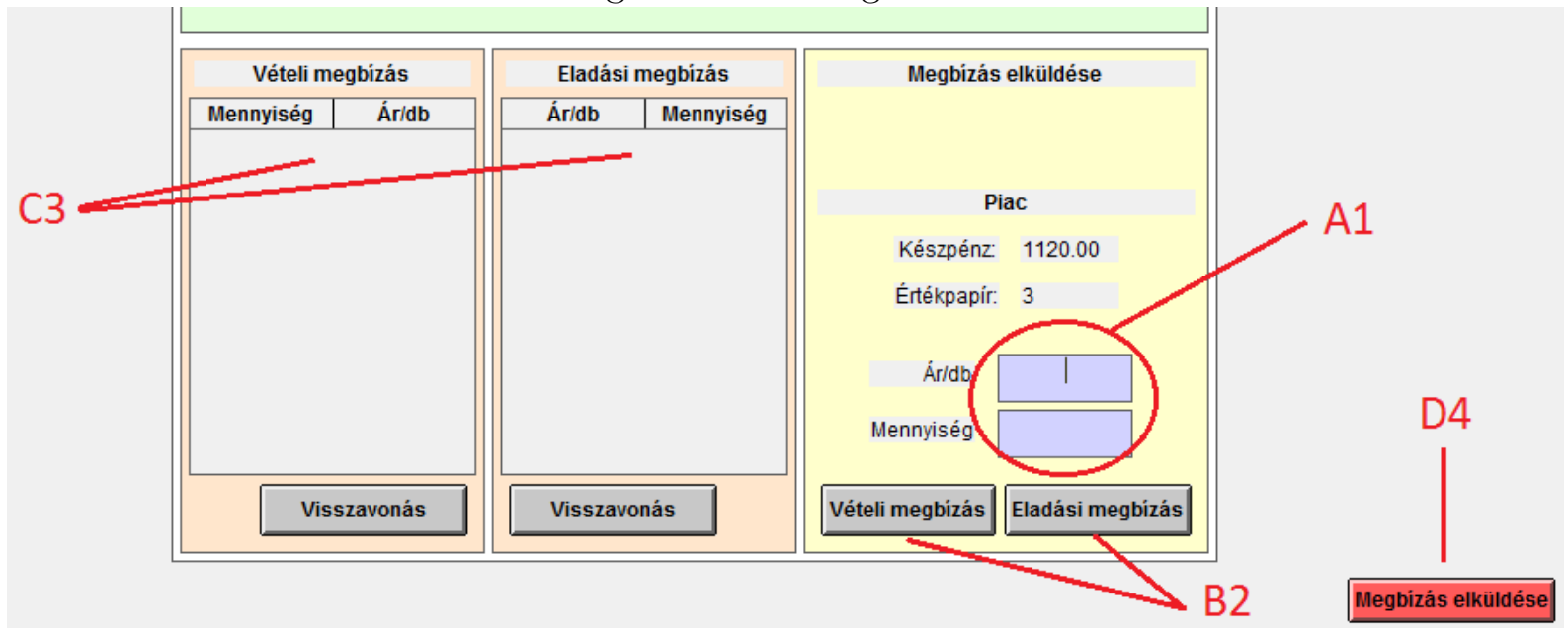

In each period you have 90 seconds to place buy and sell orders, which you can do on the bottom right corner on the trading screen with a yellow background (see Figure 4.). If you click on the 'Place buy order' button (B2), then your order in the purple container (A1) will be transferred into the order book on the left (C3).13 Your order is then marked

\footnotetext{
${ }^{13}$ Translations: 'Vteli megbzs' = 'Buy order', 'Eladsi megbzs' = 'Sell order', 'Mennyisg' = 'Amount',
} 
as sent, but you can cancel it until the end of the period. The sell order works in a similar fashion. If you have already decided on what orders to place and you transferred these to the order book, then you have two possibilities: either you wait for the remaining time to run out or you click to the 'Send order' button (D4), after which you cannot trade any more in that given period.

\section{Determining the trading price}

The trading software compiles the buy and sell orders and determines the trading price on which the assets are exchanged. Under the calculated price the maximum amount of asset exchange will take place. It is possible that there is more than one such price. In the following example we demonstrate how the trading price gets chosen.

It is important to note that if your buy order is lower than the calculated trading price, then you will not buy any assets. Sometimes it can happen that even though your buy order is higher than the trading price, you still do not manage to buy any assets. This happens because there is overdemand, and it is impossible to satisfy all claims; In such cases transactions happen in the order that the buy orders were placed. Similarly, if you have given a higher sell order than the trading price, then you will not sell any assets. In case of oversupply it can happen that you have given a sell order that is lower than the trading price, but you still do not sell any assets because the others placed orders before you.

Figure 5: Example (The labels are translated from Hungarian.)

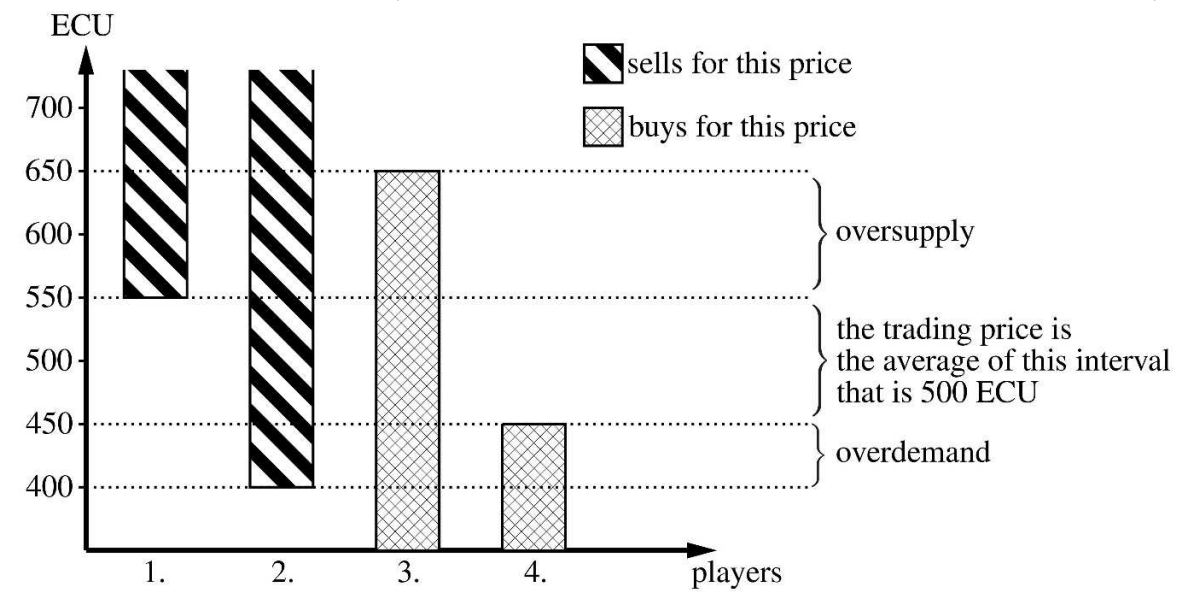

'r/db' = 'Price per quantity', 'Piac' = 'Market', 'Kszpnz' = 'Cash', 'rtkpapr' = 'Asset', 'Visszavons' = 'Cancel', 'Megbzs elkldse' = 'Send order' 


\section{Example}

As we can see in Figure 5, below 400 ECUs both Player 3 and 4 would buy, but neither Player 1 nor Player 2 is willing to sell. In this case the demand is greater than the supply: There is excess demand. Prices below 400 ECUs do not lead to transactions. For prices between 400 and 450 ECUs, both Player 3 and 4 is still willing to buy and Player 2 is willing to sell his/her asset. As there are more buyers than sellers, there is still excess demand. Similarly, above 550 ECUs both Player 1 and 2 are willing to sell their assets but only Player 3 is willing to buy. Two sellers face only one buyer, thus, there is excess supply. Above 650 ECUs the events turn into worse as there are no buyers although there are two sellers.

Between 450 and 550 ECUs Player 2 is willing to sell his/her asset and Player 3 is willing to buy for this price. This price is too high for Player 4 (who would like to buy) and too low for Player 1 (who would like to sell). That is, for such prices there is only one buyer and one seller, so there is no excess demand or supply. In such a case the trading price is the average of 450 and $550 \mathrm{ECUs}$, that is, $500 \mathrm{ECUs}$.

If oversupply drives the market, then buyers are in better position, thus, the smallest trading price will be realized. If dominantly there is overdemand on the market, then sellers are in better position, hence, the highest possible price will prevail. If there is both oversupply and overdemand, then the trading price is set as the average of the highest and lowest possible price.

To understand the decision mechanism better there will be a trial period, where you can place buy and sell orders, before entering the real market. For these decisions you will not receive any payment. In the trial period you will receive a different amount of ECUs and assets than in the real rounds, and in addition, after the end of the trial period you will not see the trading price, instead you will see what transactions took place under the different buy and sell orders.

The trial period is followed by a short query, after which you will be assigned to a computer in one of the labs for part 2 of the experiment. Please do not wander off too far during the break when you are reassigned.

\section{Payments}

Your final payment consists of three parts: 
- 1000 HUF for participating in the experiment

- the money you earn in one of the 4 questions (chosen randomly) in part 1 of the experiment

- your balance after the 15 th period in one of the rounds (chosen randomly) in part 2 of the experiment

As we mentioned earlier, we keep your balance in ECUs and pay you with the exchange rate $3 \mathrm{ECU}=1 \mathrm{HUF}$ at the end of the experiment.

If you have any further question, please indicate now! 


\section{B Appendix B: Risk tolerance and bubble/mispricing measures - first 5 periods excluded}

Table A1: Observed values of bubble and mispricing measures when excluding first 5 periods. The last row contains the p-value of the Mann-Whitney U test comparing markets 1-3 to $10-12$.

\begin{tabular}{|c|c|c|c|c|c|c|c|}
\hline \multirow{2}{*}{ Market } & \multicolumn{3}{|c|}{ Bubble measures } & \multicolumn{3}{|c|}{ Mispricing measures } & \multirow[b]{2}{*}{ Turnovel } \\
\hline & $\begin{array}{c}\text { Positive } \\
\text { Deviation }\end{array}$ & $\begin{array}{c}\text { Boom } \\
\text { Duration }\end{array}$ & $\begin{array}{c}\text { Positive } \\
\text { Amplitude }\end{array}$ & $\begin{array}{c}\text { Average } \\
\text { Bias } \\
\end{array}$ & $\begin{array}{c}\text { Total } \\
\text { Dispersion }\end{array}$ & Amplitude & \\
\hline 1 & 1795 & 8 & 490 & 199.44 & 1795 & 475 & 0.81 \\
\hline 2 & 2340 & 8 & 690 & 230 & 2380 & 730 & 1.25 \\
\hline 3 & 4180 & 7 & 800 & 522.5 & 4180 & 600 & 0.88 \\
\hline Average 1-3 & 2771.67 & 7.67 & 660.00 & 317.31 & 2785.00 & 601.67 & 0.98 \\
\hline 4 & 110.5 & 2 & 80 & -46.58 & 500.5 & 280 & 0.69 \\
\hline 5 & 2670 & 9 & 520 & 267 & 2670 & 520 & 1.13 \\
\hline 6 & 930 & 5 & 160 & 116.25 & 930 & 90 & 1.13 \\
\hline Average 4-6 & 1236.83 & 5.33 & 253.33 & 112.22 & 1366.83 & 296.67 & 0.98 \\
\hline 7 & 7180 & 5 & 1430 & 897.50 & 7180 & 1430 & 0.94 \\
\hline 8 & 430 & 8 & 100 & 47.78 & 430 & 80 & 1.56 \\
\hline 9 & 6140 & 3 & 1540 & 1023.33 & 6140 & 1120 & 0.63 \\
\hline Average 7-9 & 4583.33 & 5.33 & 1023.33 & 656.20 & 4583.33 & 876.67 & 1.04 \\
\hline 10 & 1272 & 5 & 420 & 159 & 1272 & 420 & 1.19 \\
\hline 11 & 420 & 3 & 120 & 47.5 & 460 & 160 & 1 \\
\hline 12 & 330 & 4 & 96 & 25.71 & 480 & 246 & 1 \\
\hline Average $10-12$ & 674 & 4 & 212 & 77.40 & 737.33 & 275.33 & 1.06 \\
\hline p-value & 0.0495 & 0.0463 & 0.0495 & 0.0495 & 0.0495 & 0.0495 & 0.5066 \\
\hline
\end{tabular}




\section{Appendix C: Market-level correlation between bub- ble/mispricing measures and individual character- istics}

Table A2: Pairwise correlation between market-level bubble measures and market level individual characteristics (all markets).

\begin{tabular}{|c|c|c|c|c|c|c|c|}
\hline & \multicolumn{3}{|c|}{ Bubble measures } & \multicolumn{3}{|c|}{ Mispricing measures } & \multirow[b]{2}{*}{ Turnover } \\
\hline & $\begin{array}{c}\text { Positive } \\
\text { Deviation }\end{array}$ & $\begin{array}{c}\text { Boom } \\
\text { Duration }\end{array}$ & $\begin{array}{c}\text { Positive } \\
\text { Amplitude }\end{array}$ & $\begin{array}{c}\text { Average } \\
\text { Bias }\end{array}$ & $\begin{array}{c}\text { Total } \\
\text { Dispersion }\end{array}$ & Amplitude & \\
\hline Risk (mean) & 0.0852 & 0.4717 & 0.1020 & 0.1267 & 0.0512 & -0.0851 & 0.0170 \\
\hline Risk (Std.dev.) & -0.3517 & 0.1354 & -0.3031 & -0.0986 & -0.4647 & -0.4015 & -0.0475 \\
\hline Uncertainty (mean) & 0.2183 & $0.5014^{*}$ & 0.1819 & 0.2716 & 0.1482 & -0.0507 & -0.0155 \\
\hline Uncertainty (Std.dev.) & -0.2650 & 0.4568 & -0.1997 & -0.1547 & -0.3045 & -0.2797 & 0.0961 \\
\hline $\begin{array}{c}\text { Share of risky choice } \\
\text { in stag hunt }\end{array}$ & -0.0526 & 0.3077 & -0.0870 & 0.0883 & -0.1349 & -0.1081 & 0.2440 \\
\hline Cognitive (mean) & -0.4544 & -0.0101 & -0.4533 & -0.2594 & $-0.5623^{*}$ & $-0.5904^{* *}$ & -0.0994 \\
\hline Cognitive (Std.dev.) & -0.3176 & 0.2481 & -0.4218 & -0.3552 & -0.2889 & -0.2730 & -0.3253 \\
\hline Share of female & 0.4955 & -0.3069 & $0.5056^{*}$ & 0.3220 & $0.5582^{*}$ & $0.5798^{* *}$ & $-0.7977^{* * *}$ \\
\hline
\end{tabular}

Table A3: Pairwise correlation between market-level bubble measures and market level individual characteristics (ignoring markets 7 and 9).

\begin{tabular}{crrrrrrrrr} 
& \multicolumn{3}{c}{ Bubble measures } & & \multicolumn{3}{c}{ Mispricing measures } & \\
\cline { 2 - 3 } & $\begin{array}{c}\text { Positive } \\
\text { Deviation }\end{array}$ & $\begin{array}{c}\text { Boom } \\
\text { Duration }\end{array}$ & $\begin{array}{c}\text { Positive } \\
\text { Amplitude }\end{array}$ & $\begin{array}{c}\text { Average } \\
\text { Bias }\end{array}$ & $\begin{array}{c}\text { Total } \\
\text { Dispersion }\end{array}$ & Amplitude & Turnover \\
\hline \hline Risk (mean) & 0.4861 & 0.4396 & $0.5663^{*}$ & & 0.5185 & 0.3332 & 0.0795 & -0.0672 \\
Risk (Std.dev.) & -0.1371 & 0.0713 & -0.0766 & & 0.3294 & -0.3616 & -0.2965 & -0.0680 \\
Uncertainty (mean) & 0.5357 & 0.4913 & 0.5344 & & $0.6051^{*}$ & 0.3312 & 0.0253 & -0.1276 \\
Uncertainty (Std.dev.) & 0.2131 & 0.3881 & 0.3764 & & 0.3892 & 0.0570 & 0.0274 & 0.0036 \\
Share of risky choice & 0.2768 & 0.2333 & 0.2696 & & 0.5287 & 0.0721 & 0.1126 & 0.1398 \\
in stag hunt & & & & & & & \\
Cognitive (mean) & -0.5464 & -0.1332 & -0.4979 & & -0.1097 & $-0.6638^{* *}$ & $-0.6018^{*}$ & -0.2997 \\
Cognitive (Std.dev.) & 0.0815 & 0.1051 & -0.0897 & -0.0020 & 0.0827 & 0.0833 & $-0.6578^{* *}$ \\
Share of female & 0.4691 & -0.1702 & 0.3895 & & 0.0363 & 0.5379 & 0.4671 & $-0.7486^{* *}$
\end{tabular}




\section{Appendix D: Linear regressions: Bubble/mispricing measures explained by market-level characteris- tics}

We exclude markets 7 and 9 from the analysis in this section.

Table A4: Positive deviation and market-level characteristics (OLS).

\begin{tabular}{|c|c|c|c|c|c|c|c|c|}
\hline \multirow[b]{2}{*}{ Variables } & $(1)$ & $(2)$ & $(3)$ & $(4)$ & $(5)$ & $(6)$ & $(7)$ & $(8)$ \\
\hline & \multicolumn{8}{|c|}{ Dependent variable: Positive Deviation } \\
\hline \multirow{2}{*}{ Risk mean } & 0.523 & & & & & 1.427 & & \\
\hline & $(1.935)$ & & & & & $(1.983)$ & & \\
\hline \multirow[t]{2}{*}{ Uncert. mean } & & 2.391 & & & & & 5.068 & \\
\hline & & $(3.380)$ & & & & & $(3.682)$ & \\
\hline \multirow[t]{2}{*}{ Cognitive mean } & & & -1.938 & & & & & -1.799 \\
\hline & & & $(1.201)$ & & & & & $(1.218)$ \\
\hline \multirow[t]{2}{*}{ Female share } & & & & 4.703 & & & & \\
\hline & & & & $(2.607)$ & & & & \\
\hline \multirow[t]{2}{*}{ Risky share in staghunt } & & & & & -736.8 & & & \\
\hline & & & & & $(4.428)$ & & & \\
\hline \multirow[t]{2}{*}{ Risk Std.dev. } & & & & & & -34.25 & & \\
\hline & & & & & & $(25.66)$ & & \\
\hline \multirow[t]{2}{*}{ Uncert. Std.dev. } & & & & & & & -8.033 & \\
\hline & & & & & & & $(5.467)$ & \\
\hline \multirow[t]{2}{*}{ Cognitive Std.dev. } & & & & & & & & -2.136 \\
\hline & & & & & & & & $(2.293)$ \\
\hline \multirow[t]{2}{*}{ Constant } & 2,030 & 1,144 & $5,571^{* *}$ & 38.74 & 2,725 & $2,572^{*}$ & 1,766 & $7,937^{* *}$ \\
\hline & $(1.351)$ & $(1.829)$ & $(2.099)$ & $(1.417)$ & $(2.413)$ & $(1.363)$ & $(1.782)$ & $(3.304)$ \\
\hline Observations & 12 & 12 & 12 & 12 & 12 & 12 & 12 & 12 \\
\hline$R^{2}$ & 0.007 & 0.048 & 0.207 & 0.246 & 0.003 & 0.171 & 0.232 & 0.276 \\
\hline
\end{tabular}


Table A5: Boom duration and market-level characteristics (OLS).

\begin{tabular}{|c|c|c|c|c|c|c|c|c|}
\hline \multirow[b]{2}{*}{ Variables } & $(1)$ & $(2)$ & $(3)$ & $(4)$ & $(5)$ & $(6)$ & $(7)$ & $(8)$ \\
\hline & \multicolumn{8}{|c|}{ Dependent variable: Boom Duration } \\
\hline \multirow[t]{2}{*}{ Risk_mean } & 0.003 & & & & & 0.00317 & & \\
\hline & $(0.00217)$ & & & & & $(0.00244)$ & & \\
\hline \multirow[t]{2}{*}{ Uncertainty_mean } & & 0.00596 & & & & & 0.00482 & \\
\hline & & $(0.00374)$ & & & & & $(0.00463)$ & \\
\hline \multirow[t]{2}{*}{ Cognitive_mean } & & & -0.651 & & & & & -0.642 \\
\hline & & & $(1.714)$ & & & & & $(1.822)$ \\
\hline \multirow[t]{2}{*}{ Female_share } & & & & -2.025 & & & & \\
\hline & & & & $(4.143)$ & & & & \\
\hline \multirow{2}{*}{ Risky_share_staghunt } & & & & & 3.713 & & & \\
\hline & & & & & $(5.470)$ & & & \\
\hline \multirow[t]{2}{*}{ Risk_sd } & & & & & & -0.00718 & & \\
\hline & & & & & & $(0.0331)$ & & \\
\hline \multirow[t]{2}{*}{ Uncertainty_sd } & & & & & & & 0.00349 & \\
\hline & & & & & & & $(0.00743)$ & \\
\hline \multirow[t]{2}{*}{ Cognitive_sd } & & & & & & & & 1.009 \\
\hline & & & & & & & & $(3.666)$ \\
\hline \multirow[t]{2}{*}{ Constant } & $4.326^{* *}$ & 3.175 & $7.324^{* *}$ & $7.111^{* * *}$ & 4.204 & $4.475^{* *}$ & 2.813 & 6.026 \\
\hline & $(1.598)$ & $(2.067)$ & $(3.101)$ & $(2.085)$ & $(3.081)$ & $(1.836)$ & $(2.308)$ & $(5.754)$ \\
\hline Observations & 10 & 10 & 10 & 10 & 10 & 10 & 10 & 10 \\
\hline$R^{2}$ & 0.193 & 0.241 & 0.018 & 0.029 & 0.054 & 0.199 & 0.265 & 0.028 \\
\hline
\end{tabular}

Table A6: Positive amplitude and market-level characteristics (OLS).

\begin{tabular}{|c|c|c|c|c|c|c|c|c|}
\hline \multirow[b]{2}{*}{ Variables } & $(1)$ & $(2)$ & $(3)$ & $(4)$ & $(5)$ & $(6)$ & $(7)$ & $(8)$ \\
\hline & \multicolumn{8}{|c|}{ Dependent variable: Positive Amplitude } \\
\hline \multirow[t]{2}{*}{ Risk_mean } & $0.367^{*}$ & & & & & $0.427^{*}$ & & \\
\hline & $(0.189)$ & & & & & $(0.201)$ & & \\
\hline \multirow[t]{2}{*}{ Uncertainty_mean } & & 0.616 & & & & & 0.537 & \\
\hline & & $(0.345)$ & & & & & $(0.430)$ & \\
\hline \multirow[t]{2}{*}{ Cognitive_mean } & & & -231.3 & & & & & -232.2 \\
\hline & & & $(142.5)$ & & & & & $(151.3)$ \\
\hline \multirow[t]{2}{*}{ Female_share } & & & & 440.1 & & & & \\
\hline & & & & $(367.9)$ & & & & \\
\hline \multirow[t]{2}{*}{ Risky_share_staghunt } & & & & & 407.6 & & & \\
\hline & & & & & $(514.7)$ & & & \\
\hline \multirow[t]{2}{*}{ Risk_sd } & & & & & & -2.531 & & \\
\hline & & & & & & $(2.732)$ & & \\
\hline \multirow[t]{2}{*}{ Uncertainty_sd } & & & & & & & 0.243 & \\
\hline & & & & & & & $(0.690)$ & \\
\hline \multirow[t]{2}{*}{ Cognitive_sd } & & & & & & & & -92.99 \\
\hline & & & & & & & & $(304.4)$ \\
\hline \multirow[t]{2}{*}{ Constant } & 121.3 & 37.98 & $749.7^{* *}$ & 152.6 & 131.5 & 173.8 & 12.78 & 869.3 \\
\hline & $(139.3)$ & $(190.6)$ & $(257.8)$ & $(185.1)$ & $(289.9)$ & $(151.6)$ & $(214.3)$ & $(477.8)$ \\
\hline Observations & 10 & 10 & 10 & 10 & 10 & 10 & 10 & 10 \\
\hline$R^{2}$ & 0.321 & 0.286 & 0.248 & 0.152 & 0.073 & 0.395 & 0.298 & 0.258 \\
\hline
\end{tabular}


Table A7: Average bias and market-level characteristics (OLS).

\begin{tabular}{|c|c|c|c|c|c|c|c|c|}
\hline \multirow{2}{*}{ Variables } & $(1)$ & $(2)$ & $(3)$ & $(4)$ & $(5)$ & $(6)$ & $(7)$ & $(8)$ \\
\hline & \multicolumn{8}{|c|}{ Dependent variable: Average Bias } \\
\hline \multirow[t]{2}{*}{ Risk_mean } & 0.123 & & & & & 0.109 & & \\
\hline & $(0.0715)$ & & & & & $(0.0791)$ & & \\
\hline \multirow[t]{2}{*}{ Uncertainty_mean } & & $0.255^{*}$ & & & & & 0.233 & \\
\hline & & $(0.119)$ & & & & & $(0.148)$ & \\
\hline \multirow[t]{2}{*}{ Cognitive_mean } & & & -18.62 & & & & & -18.63 \\
\hline & & & $(59.63)$ & & & & & $(63.76)$ \\
\hline \multirow[t]{2}{*}{ Female_share } & & & & 14.97 & & & & \\
\hline & & & & $(145.8)$ & & & & \\
\hline \multirow[t]{2}{*}{ Risky_share_staghunt } & & & & & 291.9 & & & \\
\hline & & & & & $(165.7)$ & & & \\
\hline \multirow[t]{2}{*}{ Risk_sd } & & & & & & 0.585 & & \\
\hline & & & & & & $(1.074)$ & & \\
\hline \multirow[t]{2}{*}{ Uncertainty_sd } & & & & & & & 0.066 & \\
\hline & & & & & & & $(0.238)$ & \\
\hline \multirow[t]{2}{*}{ Cognitive_sd } & & & & & & & & -1.43 \\
\hline & & & & & & & & $(128.3)$ \\
\hline \multirow[t]{2}{*}{ Constant } & $-106.7^{*}$ & $-159.3^{* *}$ & 2.078 & -36.78 & $-186.9^{*}$ & $-118.9^{*}$ & $-166.1^{*}$ & 3.917 \\
\hline & $(52.79)$ & $(65.57)$ & $(107.9)$ & $(73.35)$ & $(93.31)$ & $(59.60)$ & $(73.95)$ & $(201.3)$ \\
\hline Observations & 10 & 10 & 10 & 10 & 10 & 10 & 10 & 10 \\
\hline$R^{2}$ & 0.269 & 0.366 & 0.012 & 0.001 & 0.279 & 0.299 & 0.373 & 0.012 \\
\hline
\end{tabular}

Table A8: Total dispersion and market-level characteristics (OLS).

\begin{tabular}{|c|c|c|c|c|c|c|c|c|}
\hline \multirow[b]{2}{*}{ Variables } & (1) & $(2)$ & (3) & $(4)$ & (5) & (6) & $(7)$ & $(8)$ \\
\hline & \multicolumn{8}{|c|}{ Dependent variable: Total Dispersion } \\
\hline \multirow[t]{2}{*}{ Risk_mean } & 1.663 & & & & & 2.497 & & \\
\hline & $(1.663)$ & & & & & $(1.598)$ & & \\
\hline \multirow[t]{2}{*}{ Uncertainty_mean } & & 2.942 & & & & & 3.703 & \\
\hline & & $(2.963)$ & & & & & $(3.686)$ & \\
\hline \multirow[t]{2}{*}{ Cognitive_mean } & & & $-2,375^{* *}$ & & & & & $-2,370^{*}$ \\
\hline & & & $(946.3)$ & & & & & $(1.007)$ \\
\hline \multirow[t]{2}{*}{ Female_share } & & & & 4.681 & & & & \\
\hline & & & & $(2.594)$ & & & & \\
\hline \multirow[t]{2}{*}{ Risky_share_staghunt } & & & & & 839.3 & & & \\
\hline & & & & & $(4.106)$ & & & \\
\hline \multirow[t]{2}{*}{ Risk_sd } & & & & & & -35.38 & & \\
\hline & & & & & & $(21.71)$ & & \\
\hline \multirow[t]{2}{*}{ Uncertainty_sd } & & & & & & & -2.318 & \\
\hline & & & & & & & $(5.919)$ & \\
\hline \multirow[t]{2}{*}{ Cognitive_sd } & & & & & & & & 502.6 \\
\hline & & & & & & & & $(2.027)$ \\
\hline \multirow[t]{2}{*}{ Constant } & 2,220 & 1,767 & $7,357^{* * *}$ & 1,153 & 2,808 & $2,955^{* *}$ & 2,007 & $6,710^{*}$ \\
\hline & $(1,227)$ & $(1,639)$ & $(1.712)$ & $(1,305)$ & $(2,312)$ & $(1,205)$ & $(1,838)$ & $(3,181)$ \\
\hline Observations & 10 & 10 & 10 & 10 & 10 & 10 & 10 & 10 \\
\hline$R^{2}$ & 0.111 & 0.110 & 0.441 & 0.289 & 0.005 & 0.356 & 0.129 & 0.445 \\
\hline
\end{tabular}


Table A9: Amplitude and market-level characteristics (OLS).

\begin{tabular}{|c|c|c|c|c|c|c|c|c|}
\hline \multirow{2}{*}{ Variables } & $(1)$ & $(2)$ & $(3)$ & $(4)$ & $(5)$ & $(6)$ & $(7)$ & $(8)$ \\
\hline & \multicolumn{8}{|c|}{ Dependent variable: Amplitude } \\
\hline \multirow[t]{2}{*}{ Risk_mean } & 0.107 & & & & & 0.262 & & \\
\hline & $(0.474)$ & & & & & $(0.503)$ & & \\
\hline \multirow[t]{2}{*}{ Uncertainty_mean } & & 0.0606 & & & & & 0.0361 & \\
\hline & & $(0.847)$ & & & & & $(1.065)$ & \\
\hline \multirow[t]{2}{*}{ Cognitive_mean } & & & $-580.9^{*}$ & & & & & $-579.6^{*}$ \\
\hline & & & $(272.6)$ & & & & & $(290.3)$ \\
\hline \multirow[t]{2}{*}{ Female_share } & & & & 1,096 & & & & \\
\hline & & & & $(733.9)$ & & & & \\
\hline \multirow[t]{2}{*}{ Risky_share_staghunt } & & & & & 353.5 & & & \\
\hline & & & & & (1.103) & & & \\
\hline \multirow[t]{2}{*}{ Risk_sd } & & & & & & -6.562 & & \\
\hline & & & & & & $(6.837)$ & & \\
\hline \multirow[t]{2}{*}{ Uncertainty_sd } & & & & & & & 0.0749 & \\
\hline & & & & & & & $(1.710)$ & \\
\hline \multirow[t]{2}{*}{ Cognitive_sd } & & & & & & & & 139.1 \\
\hline & & & & & & & & $(584.0)$ \\
\hline \multirow[t]{2}{*}{ Constant } & $1,061^{* *}$ & $1,097^{* *}$ & $2,130^{* * *}$ & 634.3 & 937.7 & $1,197^{* *}$ & $1,089^{*}$ & $1,951^{*}$ \\
\hline & $(350.1)$ & $(468.4)$ & $(493.3)$ & $(369.2)$ & $(621.4)$ & $(379.4)$ & $(531.1)$ & $(916.5)$ \\
\hline Observations & 10 & 10 & 10 & 10 & 10 & 10 & 10 & 10 \\
\hline$R^{2}$ & 0.006 & 0.001 & 0.362 & 0.218 & 0.013 & 0.122 & 0.001 & 0.367 \\
\hline
\end{tabular}

Table A10: Turnover and market-level characteristics (OLS).

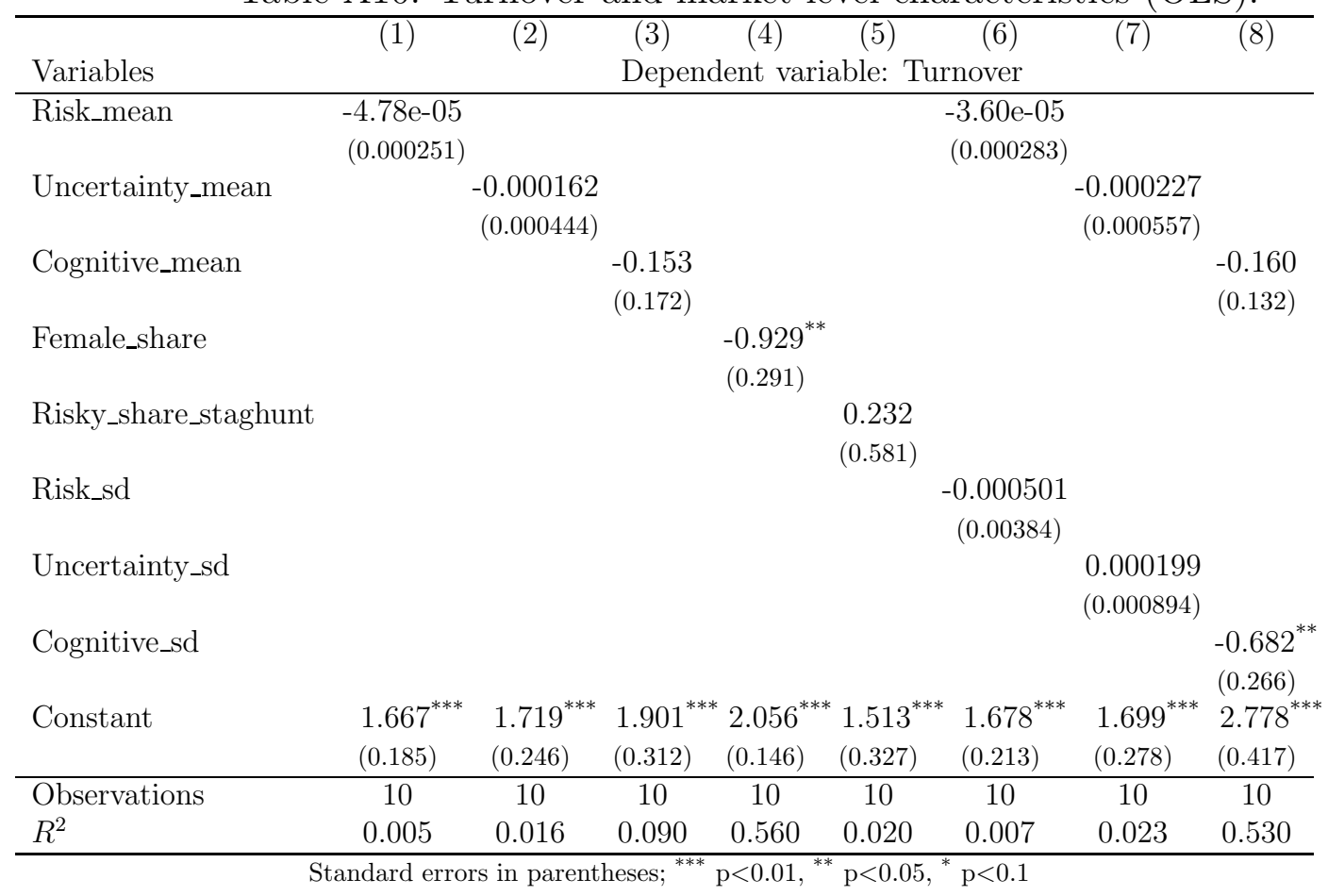




\section{E Appendix E: Excess buy and excess sell orders}

Table A11: Excess sell orders: Random-effects panel regressions with individual characteristics.

\begin{tabular}{|c|c|c|c|c|c|}
\hline \multirow[b]{2}{*}{ Variables } & (1) & $(2)$ & $(3)$ & $(4)$ & (5) \\
\hline & \multicolumn{5}{|c|}{ Dependent variable: Excess sell order } \\
\hline Risk Tolerance & $\begin{array}{c}-0.0379 \\
(0.210)\end{array}$ & & & & $\begin{array}{c}-0.0814 \\
(0.218)\end{array}$ \\
\hline Cognitive Abilities & & $\begin{array}{r}-43.37 \\
(45.76)\end{array}$ & & & $\begin{array}{c}-38.41 \\
(35.63)\end{array}$ \\
\hline Female & & & $\begin{array}{c}118.5 \\
(120.9)\end{array}$ & & $\begin{array}{c}104.8 \\
(103.3)\end{array}$ \\
\hline Strategic Uncertainty & & & & $\begin{array}{c}116.8 \\
(116.7)\end{array}$ & $\begin{array}{c}132.3 \\
(129.5)\end{array}$ \\
\hline Assets (lagged) & $\begin{array}{c}-55.22^{* *} \\
(25.61)\end{array}$ & $\begin{array}{c}-51.47^{* *} \\
(25.71)\end{array}$ & $\begin{array}{c}-50.30^{*} \\
(26.27)\end{array}$ & $\begin{array}{c}-56.32^{* *} \\
(25.27)\end{array}$ & $\begin{array}{r}-51.21^{*} \\
(29.12)\end{array}$ \\
\hline Cash (lagged) & $\begin{array}{c}0.0186 \\
(0.0270)\end{array}$ & $\begin{array}{c}0.0222 \\
(0.0278)\end{array}$ & $\begin{array}{c}0.0227 \\
(0.0276)\end{array}$ & $\begin{array}{c}0.0191 \\
(0.0278)\end{array}$ & $\begin{array}{c}0.0231 \\
(0.0289)\end{array}$ \\
\hline Market Price (lagged) & $\begin{array}{c}0.349^{* *} \\
(0.167)\end{array}$ & $\begin{array}{c}0.330^{*} \\
(0.172)\end{array}$ & $\begin{array}{c}0.331^{*} \\
(0.171)\end{array}$ & $\begin{array}{c}0.337^{*} \\
(0.174)\end{array}$ & $\begin{array}{c}0.330^{*} \\
(0.169)\end{array}$ \\
\hline Dividend (lagged) & $\begin{array}{c}0.0141 \\
(0.268)\end{array}$ & $\begin{array}{c}-0.00145 \\
(0.262)\end{array}$ & $\begin{array}{l}0.00433 \\
(0.262)\end{array}$ & $\begin{array}{c}0.00429 \\
(0.259)\end{array}$ & $\begin{array}{c}-0.00291 \\
(0.265)\end{array}$ \\
\hline Remaining Period & $\begin{array}{l}-4.100 \\
(44.32)\end{array}$ & $\begin{array}{r}2.657 \\
(47.43)\end{array}$ & $\begin{array}{r}1.761 \\
(47.60)\end{array}$ & $\begin{array}{l}-0.649 \\
(50.51)\end{array}$ & $\begin{array}{r}3.961 \\
(43.49)\end{array}$ \\
\hline Remaining Period Squared & $\begin{array}{c}0.268 \\
(3.291)\end{array}$ & $\begin{array}{c}-0.00382 \\
(3.402)\end{array}$ & $\begin{array}{c}0.0666 \\
(3.453)\end{array}$ & $\begin{array}{c}0.0733 \\
(3.599)\end{array}$ & $\begin{array}{c}-0.0623 \\
(3.242)\end{array}$ \\
\hline Constant & $\begin{array}{c}203.2 \\
(278.0)\end{array}$ & $\begin{array}{c}224.1 \\
(224.1)\end{array}$ & $\begin{array}{r}92.27 \\
(262.4)\end{array}$ & $\begin{array}{c}115.7 \\
(252.8)\end{array}$ & $\begin{array}{c}136.9 \\
(289.6)\end{array}$ \\
\hline Observations & 436 & 436 & 436 & 436 & 436 \\
\hline Prob $>\chi^{2}$ & 0.000906 & 0.000389 & 0.000804 & 0.00597 & $5.26 e-05$ \\
\hline
\end{tabular}


Table A12: Excess sell order: Random-effects panel regressions with market-level characteristics.

\begin{tabular}{|c|c|c|c|c|c|}
\hline \multirow[b]{2}{*}{ Variables } & (1) & $(2)$ & $(3)$ & $(4)$ & $(5)$ \\
\hline & \multicolumn{5}{|c|}{ Dependent variable: Excess sell order } \\
\hline Risk Tol. Average & $\begin{array}{c}-0.0522 \\
(0.234)\end{array}$ & & & & $\begin{array}{r}-0.217 \\
(0.255)\end{array}$ \\
\hline Risk Tol. St.Dev. & $\begin{array}{c}1.825 \\
(2.137)\end{array}$ & & & & $\begin{array}{c}4.839 \\
(3.817)\end{array}$ \\
\hline Cognitive Average & & $\begin{array}{r}-97.02 \\
(87.18)\end{array}$ & & & $\begin{array}{r}-218.9^{* *} \\
(88.80)\end{array}$ \\
\hline Cognitive St.Dev. & & $\begin{array}{c}398.1^{* *} \\
(177.9)\end{array}$ & & & $\begin{array}{c}197.9 \\
(162.8)\end{array}$ \\
\hline Share of Females & & & $\begin{array}{c}44.03^{* *} \\
(20.84)\end{array}$ & & $\begin{array}{c}55.02 \\
(33.97)\end{array}$ \\
\hline Str.Uncertainty Average & & & & $\begin{array}{c}111.7 \\
(386.2)\end{array}$ & $\begin{array}{c}-466.8 \\
(530.2)\end{array}$ \\
\hline Assets (lagged) & $\begin{array}{c}-56.93^{* *} \\
(26.94)\end{array}$ & $\begin{array}{c}-58.44^{* *} \\
(25.14)\end{array}$ & $\begin{array}{c}-55.72^{* *} \\
(24.76)\end{array}$ & $\begin{array}{c}-54.96^{* *} \\
(24.30)\end{array}$ & $\begin{array}{c}-63.07^{* *} \\
(28.09)\end{array}$ \\
\hline Cash (lagged) & $\begin{array}{c}0.0177 \\
(0.0280)\end{array}$ & $\begin{array}{c}0.0170 \\
(0.0273)\end{array}$ & $\begin{array}{c}0.0185 \\
(0.0267)\end{array}$ & $\begin{array}{c}0.0190 \\
(0.0276)\end{array}$ & $\begin{array}{c}0.0126 \\
(0.0274)\end{array}$ \\
\hline Market Price (lagged) & $\begin{array}{c}0.351^{* *} \\
(0.166)\end{array}$ & $\begin{array}{c}0.319^{*} \\
(0.172)\end{array}$ & $\begin{array}{c}0.315^{*} \\
(0.177)\end{array}$ & $\begin{array}{c}0.337^{* *} \\
(0.172)\end{array}$ & $\begin{array}{c}0.322^{*} \\
(0.168)\end{array}$ \\
\hline Dividend (lagged) & $\begin{array}{r}0.0115 \\
(0.268)\end{array}$ & $\begin{array}{r}-0.0138 \\
(0.263)\end{array}$ & $\begin{array}{r}0.0150 \\
(0.264)\end{array}$ & $\begin{array}{c}0.00747 \\
(0.262)\end{array}$ & $\begin{array}{r}-0.0152 \\
(0.264)\end{array}$ \\
\hline Remaining Period & $\begin{array}{l}-4.723 \\
(43.51)\end{array}$ & $\begin{array}{r}2.318 \\
(48.24)\end{array}$ & $\begin{array}{r}3.377 \\
(50.27)\end{array}$ & $\begin{array}{l}-1.166 \\
(48.38)\end{array}$ & $\begin{array}{r}1.020 \\
(44.40)\end{array}$ \\
\hline Remaining Period Squared & $\begin{array}{c}0.262 \\
(3.266)\end{array}$ & $\begin{array}{c}-0.101 \\
(3.449)\end{array}$ & $\begin{array}{r}-0.120 \\
(3.594)\end{array}$ & $\begin{array}{c}0.120 \\
(3.439)\end{array}$ & $\begin{array}{r}-0.125 \\
(3.338)\end{array}$ \\
\hline Constant & $\begin{array}{c}155.2 \\
(261.3)\end{array}$ & $\begin{array}{c}-131.2 \\
(281.9)\end{array}$ & $\begin{array}{r}34.41 \\
(206.2)\end{array}$ & $\begin{array}{c}118.2 \\
(318.1)\end{array}$ & $\begin{array}{c}386.7 \\
(392.8)\end{array}$ \\
\hline Observations & 436 & 436 & 436 & 436 & 436 \\
\hline Prob $>\chi^{2}$ & 0.000213 & $1.38 e-07$ & $2.03 e-05$ & 0.00194 & $2.78 e-10$ \\
\hline
\end{tabular}




\section{F Appendix F: Relative excess buy and sell orders}

Here we report the results of the panel regressions that follow the same structure as those in the main text but with the dependent variable being relative excess buy (sell) order defined as excess buy (sell) order divided by the fundamental value in the given period. When running the regressions represented in Tables A13 and A14, we eliminate irrational buy/sell orders that exceed the fundamental value by more than $100 \%$.

Table A13: Relative excess buy order: Random-effects panel regressions with individual characteristics.

\begin{tabular}{|c|c|c|c|c|c|}
\hline \multirow[b]{2}{*}{ Variables } & $(1)$ & $(2)$ & $(3)$ & $(4)$ & (5) \\
\hline & \multicolumn{5}{|c|}{ Dependent variable: Relative excess buy order } \\
\hline RiskTolerance & $\begin{array}{c}0.000136^{* *} \\
(5.53 e-05)\end{array}$ & & & & $\begin{array}{r}8.01 e-05 \\
(4.89 e-05)\end{array}$ \\
\hline CognitiveAbilities & & $\begin{array}{c}-0.0461^{* * *} \\
(0.0162)\end{array}$ & & & $\begin{array}{c}-0.0345^{* *} \\
(0.0152)\end{array}$ \\
\hline Female & & & $\begin{array}{l}0.0794^{* *} \\
(0.0351)\end{array}$ & & $\begin{array}{c}0.0627^{*} \\
(0.0350)\end{array}$ \\
\hline StrategicUncertainty & & & & $\begin{array}{c}0.0559 \\
(0.0358)\end{array}$ & $\begin{array}{c}0.0569^{*} \\
(0.0333)\end{array}$ \\
\hline Assets_lagged & $\begin{array}{c}-0.00883 \\
(0.0102)\end{array}$ & $\begin{array}{c}-0.00551 \\
(0.00973)\end{array}$ & $\begin{array}{c}-0.00529 \\
(0.0114)\end{array}$ & $\begin{array}{c}-0.00706 \\
(0.0106)\end{array}$ & $\begin{array}{r}-0.00719 \\
(0.00864)\end{array}$ \\
\hline Cash_lagged & $\begin{array}{r}-2.22 e-06 \\
(9.90 e-06)\end{array}$ & $\begin{array}{r}-2.21 e-06 \\
(9.67 e-06)\end{array}$ & $\begin{array}{c}4.59 e-07 \\
(9.98 e-06)\end{array}$ & $\begin{array}{r}-2.07 e-07 \\
(9.72 e-06)\end{array}$ & $\begin{array}{c}7.68 e-07 \\
(8.36 e-06)\end{array}$ \\
\hline MarketPrice_lagged & $\begin{array}{c}0.000212^{* *} \\
(8.92 e-05)\end{array}$ & $\begin{array}{c}0.000247^{* * *} \\
(8.91 e-05)\end{array}$ & $\begin{array}{c}0.000237^{* * *} \\
(8.99 e-05)\end{array}$ & $\begin{array}{c}0.000279^{* * *} \\
(8.82 e-05)\end{array}$ & $\begin{array}{c}0.000209^{* *} \\
(8.60 e-05)\end{array}$ \\
\hline Dividend_lagged & $\begin{array}{c}-1.50 e-05 \\
(0.000127)\end{array}$ & $\begin{array}{c}-3.31 e-05 \\
(0.000128)\end{array}$ & $\begin{array}{c}2.30 e-07 \\
(0.000128)\end{array}$ & $\begin{array}{c}-9.85 e-06 \\
(0.000130)\end{array}$ & $\begin{array}{c}-4.47 e-05 \\
(0.000130)\end{array}$ \\
\hline RemainingPeriod & $\begin{array}{c}-0.0528^{* *} \\
(0.0269)\end{array}$ & $\begin{array}{c}-0.0635^{* *} \\
(0.0280)\end{array}$ & $\begin{array}{c}-0.0621^{* *} \\
(0.0260)\end{array}$ & $\begin{array}{c}-0.0654^{* *} \\
(0.0260)\end{array}$ & $\begin{array}{c}-0.0561^{*} \\
(0.0300)\end{array}$ \\
\hline RemainingPeriodSquared & $\begin{array}{c}0.00126 \\
(0.00182)\end{array}$ & $\begin{array}{c}0.00193 \\
(0.00181)\end{array}$ & $\begin{array}{c}0.00196 \\
(0.00175)\end{array}$ & $\begin{array}{c}0.00188 \\
(0.00176)\end{array}$ & $\begin{array}{c}0.00159 \\
(0.00200)\end{array}$ \\
\hline Constant & $\begin{array}{c}0.194^{*} \\
(0.103)\end{array}$ & $\begin{array}{c}0.344^{* * *} \\
(0.0892)\end{array}$ & $\begin{array}{c}0.221^{* *} \\
(0.0913)\end{array}$ & $\begin{array}{c}0.210^{* *} \\
(0.0967)\end{array}$ & $\begin{array}{c}0.215^{* *} \\
(0.0984)\end{array}$ \\
\hline Observations & 190 & 190 & 190 & 190 & 190 \\
\hline Prob $>\chi^{2}$ & 0.000201 & $1.10 e-07$ & $5.21 e-05$ & $5.13 e-05$ & $1.68 e-08$ \\
\hline
\end{tabular}


Table A14: Relative excess sell order: Random-effects panel regressions with individual characteristics.

\begin{tabular}{|c|c|c|c|c|c|}
\hline \multirow[b]{2}{*}{ Variables } & (1) & (2) & (3) & (4) & (5) \\
\hline & \multicolumn{5}{|c|}{ Dependent variable: Relative excess sell order } \\
\hline RiskTolerance & $\begin{array}{c}8.53 e-05^{*} \\
(4.69 e-05)\end{array}$ & & & & $\begin{array}{c}7.40 e-05 \\
(5.16 e-05)\end{array}$ \\
\hline CognitiveAbilities & & $\begin{array}{c}-0.0134 \\
(0.0177)\end{array}$ & & & $\begin{array}{c}-0.00863 \\
(0.0185)\end{array}$ \\
\hline Female & & & $\begin{array}{c}0.0363 \\
(0.0463)\end{array}$ & & $\begin{array}{c}0.0346 \\
(0.0481)\end{array}$ \\
\hline StrategicUncertainty & & & & $\begin{array}{c}0.0523 \\
(0.0465)\end{array}$ & $\begin{array}{c}0.0489 \\
(0.0464)\end{array}$ \\
\hline Assets_lagged & $\begin{array}{c}-0.0342^{* * *} \\
(0.0105)\end{array}$ & $\begin{array}{c}-0.0347^{* * *} \\
(0.0111)\end{array}$ & $\begin{array}{c}-0.0348^{* * *} \\
(0.0106)\end{array}$ & $\begin{array}{c}-0.0366^{* * *} \\
(0.0107)\end{array}$ & $\begin{array}{c}-0.0333^{* * *} \\
(0.0110)\end{array}$ \\
\hline Cash_lagged & $\begin{array}{c}8.49 e-06 \\
(1.03 e-05)\end{array}$ & $\begin{array}{c}7.46 e-06 \\
(1.07 e-05)\end{array}$ & $\begin{array}{c}7.45 e-06 \\
(1.03 e-05)\end{array}$ & $\begin{array}{c}6.35 e-06 \\
(1.06 e-05)\end{array}$ & $\begin{array}{r}9.61 e-06 \\
(1.05 e-05)\end{array}$ \\
\hline MarketPrice_lagged & $\begin{array}{c}0.000326^{* * *} \\
(6.02 e-05)\end{array}$ & $\begin{array}{c}0.000339^{* * *} \\
(6.03 e-05)\end{array}$ & $\begin{array}{c}0.000340^{* * *} \\
(5.95 e-05)\end{array}$ & $\begin{array}{c}0.000339^{* * *} \\
(6.01 e-05)\end{array}$ & $\begin{array}{c}0.000320^{* * *} \\
(6.05 e-05)\end{array}$ \\
\hline Dividend_lagged & $\begin{array}{l}1.82 e-05 \\
(0.000104)\end{array}$ & $\begin{array}{c}2.02 e-05 \\
(0.000105)\end{array}$ & $\begin{array}{c}2.37 e-05 \\
(0.000103)\end{array}$ & $\begin{array}{c}2.30 e-05 \\
(0.000103)\end{array}$ & $\begin{array}{l}1.26 e-05 \\
(0.000105)\end{array}$ \\
\hline RemainingPeriod & $\begin{array}{c}-0.0830^{* * *} \\
(0.0162)\end{array}$ & $\begin{array}{c}-0.0858^{* * *} \\
(0.0163)\end{array}$ & $\begin{array}{c}-0.0865^{* * *} \\
(0.0160)\end{array}$ & $\begin{array}{c}-0.0860^{* * *} \\
(0.0165)\end{array}$ & $\begin{array}{c}-0.0808^{* * *} \\
(0.0165)\end{array}$ \\
\hline RemainingPeriodSquared & $\begin{array}{c}0.00317^{* * *} \\
(0.000943)\end{array}$ & $\begin{array}{c}0.00330^{* * *} \\
(0.000936)\end{array}$ & $\begin{array}{c}0.00334^{* * *} \\
(0.000938)\end{array}$ & $\begin{array}{c}0.00328^{* * *} \\
(0.000959)\end{array}$ & $\begin{array}{c}0.00308^{* * *} \\
(0.000953)\end{array}$ \\
\hline Constant & $\begin{array}{l}0.380^{* * *} \\
(0.101) \\
\end{array}$ & $\begin{array}{l}0.460^{* * *} \\
(0.0890) \\
\end{array}$ & $\begin{array}{l}0.423^{* * *} \\
(0.0937) \\
\end{array}$ & $\begin{array}{l}0.418^{* * *} \\
(0.0990) \\
\end{array}$ & $\begin{array}{l}0.351^{* * *} \\
(0.111) \\
\end{array}$ \\
\hline Observations & 324 & 324 & 324 & 324 & 324 \\
\hline Prob $>\chi^{2}$ & 0 & 0 & 0 & 0 & 0 \\
\hline
\end{tabular}




\section{G Appendix G: Price evolution in round 2}

Figure 6: Price evolution in round 2. (Top left pane: markets 1-3 populated by the most risk-tolerant traders. Top right pane: markets 4-6, second most risk-tolerant set of markets. Bottom left pane: markets 7-9, third most risk-tolerant quartile of markets. Bottom right pane: markets 10-12 populated by the least risk-tolerant traders.)
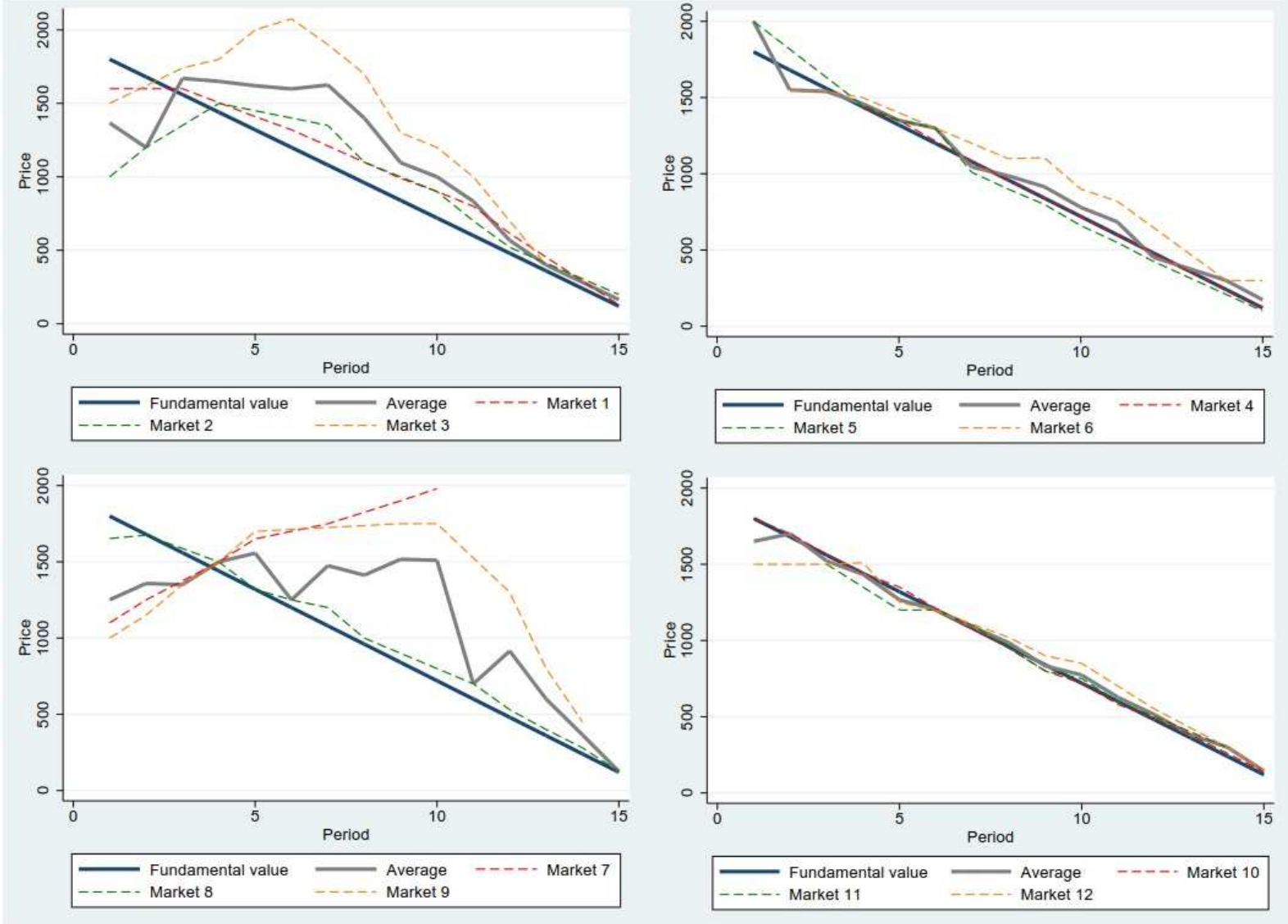


\section{H Appendix H: Bubble/mispricing measures in round 2}

Table A15: Observed values of bubble and mispricing measures in round 2. The last row contains the p-value of the Mann-Whitney U test comparing markets 1-3 to 10-12.

\begin{tabular}{|c|c|c|c|c|c|c|c|}
\hline & \multicolumn{3}{|c|}{ Bubble measures } & \multicolumn{3}{|c|}{ Mispricing measures } & \multirow[b]{2}{*}{ Turnover } \\
\hline & $\begin{array}{c}\text { Positive } \\
\text { Deviation }\end{array}$ & $\begin{array}{c}\text { Boom } \\
\text { Duration }\end{array}$ & $\begin{array}{l}\text { Positive } \\
\text { Amplitude }\end{array}$ & $\begin{array}{c}\text { Average } \\
\text { Bias }\end{array}$ & $\begin{array}{c}\text { Total } \\
\text { Dispersion }\end{array}$ & Amplitude & \\
\hline 1 & 925 & 4 & 200 & 80.56 & 1125 & 400 & 0.81 \\
\hline 2 & 1359 & 9 & 270 & 6.58 & 2639 & 1070 & 1.69 \\
\hline 3 & 5035 & 9 & 875 & 430.45 & 5335 & 1175 & 1.06 \\
\hline Average 1-3 & 2439.67 & 7.33 & 448.33 & 172.53 & 3033 & 881.67 & 1.19 \\
\hline 4 & 33 & 3 & 30 & 3.07 & 44 & 40 & 0.75 \\
\hline 5 & 340 & 3 & 200 & -1.45 & 696 & 270 & 1.19 \\
\hline 6 & 1105 & 4 & 265 & 106.11 & 1255 & 395 & 1.13 \\
\hline Average 4-6 & 492.5 & 3.33 & 165 & 35.91 & 664.83 & 235 & 1.02 \\
\hline 7 & 4245 & 4 & 1260 & 389.38 & 5375 & 1960 & 1.06 \\
\hline 8 & 645 & 10 & 120 & 35.18 & 797.5 & 267.5 & 2.5 \\
\hline 9 & 3850 & 3 & 1030 & 231 & 5390 & 1830 & 0.94 \\
\hline Average 7-9 & 2913.33 & 5.67 & 803.33 & 218.52 & 3854.17 & 1352.5 & 1.5 \\
\hline 10 & 115 & 3 & 30 & 3.21 & 185 & 70 & 1.94 \\
\hline 11 & 130 & 1 & 60 & -18 & 440 & 180 & 1.19 \\
\hline 12 & 580 & 5 & 130 & 12.08 & 1015 & 430 & 1.5 \\
\hline Average $10-12$ & 275 & 3 & 73.33 & -0.90 & 546.67 & 226.67 & 1.54 \\
\hline p-value & 0.0495 & 0.1212 & 0.0495 & 0.1266 & 0.0495 & 0.1266 & 0.2752 \\
\hline
\end{tabular}




\section{Appendix I: Comparing bubble/mispricing measures across rounds}

Table A16: Comparing mispricing measures across rounds.

\begin{tabular}{rrccccc} 
& \multicolumn{3}{c}{ Average 1-3 } & \multicolumn{3}{c}{ Average 4-6 } \\
& Round 1 & Round 2 & p-values & Round 1 & Round 2 & p-values \\
\hline Positive Deviation & 2771.67 & 2439.67 & 0.5127 & 1273.50 & 492.5 & 0.5127 \\
Boom Duration & 7.67 & 7.33 & 0.5002 & 5.67 & 3.33 & 0.5066 \\
Positive Amplitude & 660.00 & 448.33 & 0.5127 & 253.33 & 165 & 0.8273 \\
Average Bias & 37.05 & 172.53 & 0.5127 & -54.96 & 35.91 & 0.0495 \\
Total Dispersion & 5101.67 & 3033 & 0.2752 & 3116.83 & 664.83 & 0.0495 \\
Amplitude & 1493.33 & 881.67 & 0.2752 & 1033.33 & 235 & 0.0495 \\
Turnover & 1.65 & 1.19 & 0.2752 & 1.58 & 1.02 & 0.0495 \\
& \multicolumn{7}{c}{ Average 7-9 } & \multicolumn{4}{c}{ Average 10-12 } \\
Round 1 & Round 2 & p-values & Round 1 & Round 2 & p-values \\
\hline Positive Deviation & 4646.67 & 2913.33 & 0.5127 & 674 & 275 & 0.2752 \\
Boom Duration & 6 & 5.67 & 0.8222 & 4 & 3 & 0.5002 \\
Positive Amplitude & 1033.33 & 803.33 & 0.2752 & 212 & 73.33 & 0.2752 \\
Average Bias & 220.97 & 218.52 & 0.8273 & -93.01 & -0.90 & 0.5127 \\
Total Dispersion & 6726.67 & 3854.17 & 0.2752 & 2373.33 & 546.67 & 0.0495 \\
Amplitude & 1760.00 & 1352.5 & 0.2752 & 1122.33 & 226.67 & 0.0495 \\
Turnover & 1.63 & 1.5 & 0.5127 & 1.56 & 1.54 & 1.0000
\end{tabular}

\section{References}

Akiyama, E., N. Hanaki, and R. Ishikawa (2017). It is not just confusion! strategic uncertainty in an experimental asset market. The Economic Journal 127(605), F563F580.

Andersson, O., H. J. Holm, J.-R. Tyran, and E. Wengström (2016). Risk aversion relates to cognitive ability: Preferences or noise? Journal of the European Economic Association 14(5), 1129-1154.

Benjamin, D. J., S. A. Brown, and J. M. Shapiro (2013). Who is 'behavioral'? cognitive ability and anomalous preferences. Journal of the European Economic Association 11(6), 1231-1255.

Bosch-Rosa, C., T. Meissner, and A. Bosch-Domènech (2018). Cognitive bubbles. Experimental Economics 21(1), 132-153.

Breaban, A. and C. N. Noussair (2015). Trader characteristics and fundamental value 
trajectories in an asset market experiment. Journal of Behavioral and Experimental Finance 8, 1-17.

Burks, S. V., J. P. Carpenter, L. Goette, and A. Rustichini (2009). Cognitive skills affect economic preferences, strategic behavior, and job attachment. Proceedings of the National Academy of Sciences 106(19), 7745-7750.

Crosetto, P. and A. Filippin (2013). The bomb risk elicitation task. Journal of Risk and Uncertainty $47(1), 31-65$.

Croson, R. and U. Gneezy (2009). Gender differences in preferences. Journal of Economic Literature $47(2), 448-74$.

Cueva, C. and A. Rustichini (2015). Is financial instability male-driven? gender and cognitive skills in experimental asset markets. Journal of Economic Behavior \& Organization 119, 330-344.

Dohmen, T., A. Falk, D. Huffman, and U. Sunde (2010). Are risk aversion and impatience related to cognitive ability? American Economic Review 100(3), 1238-60.

Dohmen, T., A. Falk, D. Huffman, and U. Sunde (2018). On the relationship between cognitive ability and risk preference. Journal of Economic Perspectives 32(2), 115-34.

Dufwenberg, M., T. Lindqvist, and E. Moore (2005). Bubbles and experience: An experiment. American Economic Review 95(5), 1731-1737.

Eckel, C. C. and S. C. Füllbrunn (2015). Thar she blows? gender, competition, and bubbles in experimental asset markets. American Economic Review 105(2), 906-920.

Eckel, C. C. and S. C. Füllbrunn (2017). Hidden vs. known gender effects in experimental asset markets. Economics Letters 156, 7-9.

Eckel, C. C. and P. J. Grossman (2008). Men, women and risk aversion: Experimental evidence. In C. Plott and V. Smith (Eds.), Handbook of Experimental Economics Results, Chapter 113, pp. 1061-1073. New York: Elsevier.

El-Sehity, T., H. Haumer, C. Helmenstein, E. Kirchler, and B. Maciejovsky (2002). Hindsight bias and individual risk attitude within the context of experimental asset markets. Journal of Psychology and Financial Markets 3(4), 227-235. 
European Parliament (2014). On Markets in Financial Instruments and Amending Directive 2002/92/EC and Directive 2011/61/EU . (EP Directive 2014/65/EU).

European Parliament (2016). On Insurance Distribution. (EP Directive 2016/97/EU).

Fellner, G. and B. Maciejovsky (2007). Risk attitude and market behavior: Evidence from experimental asset markets. Journal of Economic Psychology 28(3), 338-350.

Filippin, A. and P. Crosetto (2016). A reconsideration of gender differences in risk attitudes. Management Science 62(11), 3138-3160.

Fischbacher, U. (2007). z-tree: Zurich toolbox for ready-made economic experiments. Experimental Economics 10(2), 171-178.

Fossen, F. (2012). Risk attitudes and private business equity. In D. Cummings (Ed.), The Oxford Handbook of Entrepreneurial Finance. New York: Oxford University Press.

Frederick, S. (2005). Cognitive reflection and decision making. Journal of Economic Perspectives 19(4), 25-42.

Green, C., J. N., and T. Y. (2009). Gender and job performance: Evidence from wall street. Financial Analysts Journal 65(6), 65-78.

Hanaki, N., E. Akiyama, Y. Funaki, R. Ishikawa, et al. (2017). Diversity in cognitive ability enlarges mispricing in experimental asset markets. Technical report, Groupe de REcherche en Droit, Economie, Gestion (GREDEG CNRS), University of Nice Sophia Antipolis.

Hanaki, N., E. Akiyama, and R. Ishikawa (2018a). Behavioral uncertainty and the dynamics of traders confidence in their price forecasts. Journal of Economic Dynamics and Control 88, 121-136.

Hanaki, N., E. Akiyama, and R. Ishikawa (2018b). Effects of different ways of incentivizing price forecasts on market dynamics and individual decisions in asset market experiments. Journal of Economic Dynamics and Control 88, 51-69.

Haruvy, E., Y. Lahav, and C. N. Noussair (2007). Traders' expectations in asset markets: Experimental evidence. American Economic Review 97(5), 1901-1920. 
Holt, C. A., M. Porzio, and M. Y. Song (2017). Price bubbles, gender, and expectations in experimental asset markets. European Economic Review 100, 72-94.

Horn, D. and H. J. Kiss (2018). Which preferences associate with school performance? Lessons from an exploratory study with university students. PloS one 13(2), e0190163.

Janssen, D. (2017). Birds of a Feather: Price Dynamics and Trading Behavior in Composed Markets. Ph. D. thesis, [Sl: sn].

Janssen, D.-J., S. Füllbrunn, and U. Weitzel (2018). Individual speculative behavior and overpricing in experimental asset markets. Experimental Economics, 1-23.

King, R. R. (1991). Private information acquisition in experimental markets prone to bubble and crash. Journal of Financial Research 14(3), 197-206.

King, R. R., V. L. Smith, A. W. Williams, and M. V. van Boening (1993). The robustness of bubbles and crashes in experimental stock markets. In R. H. Day and P. Chen (Eds.), Nonlinear Dynamics and Evolutionary Economics. New York: Oxford University Press.

Kirchler, E. and B. Maciejovsky (2002). Simultaneous over- and underconfidence: Evidence from experimental asset markets. Journal of Risk and Uncertainty 25(1), 65-85.

Kirchler, E., B. Maciejovsky, and M. Weber (2005). Framing effects, selective information, and market behavior: An experimental analysis. Journal of Behavioral Finance 6(2), 90-100.

Kocher, M. G., K. E. Lucks, and D. Schindler (2018). Unleashing animal spirits: Selfcontrol and overpricing in experimental asset markets. The Review of Financial Studies, hhy109.

Lazear, E. P. and K. L. Shaw (2007, November). Personnel economics: The economist's view of human resources. Working Paper 13653, National Bureau of Economic Research.

Lei, V., C. N. Noussair, and C. R. Plott (2001). Nonspeculative bubbles in experimental asset markets: Lack of common knowledge of rationality vs. actual irrationality. Econometrica 69(4), 831-859.

Lei, V. and F. Vesely (2009). Market efficiency: Evidence from a no-bubble asset market experiment. Pacific Economic Review 14(2), 246-258. 
Maciejovsky, B., E. Kirchler, and H. Schwarzenberger (2007). Misperception of chance and loss repair: On the dynamics of tax compliance. Journal of Economic Psychology 28(6), $678-691$.

Miller, R. M. (2002). Can markets learn to avoid bubbles? Journal of Psychology and Financial Markets 3(1), 44-52.

Noussair, C. N. and O. Powell (2010). Peaks and valleys: Price discovery in experimental asset markets with non-monotonic fundamentals. Journal of Economic Studies 37(2), $152-180$.

Oechssler, J., C. Schmidt, and W. Schnedler (2011). On the ingredients for bubble formation: Informed traders and communication. Journal of Economic Dynamics and Control 35(11), 1831-1851.

Palan, S. (2013). A review of bubbles and crashes in experimental asset markets. Journal of Economic Surveys 27(3), 570-588.

Palan, S. (2015). Gims-software for asset market experiments. Journal of Behavioral and Experimental Finance 5, 1-14.

Porter, D. P. and V. L. Smith (1995). Futures contracting and dividend uncertainty in experimental asset markets. The Journal of Business 68(4), 509-541.

Porter, D. P. and V. L. Smith (2008). Price bubbles. In C. Plott and V. Smith (Eds.), Handbook of Experimental Economics Results, Chapter 30, pp. 247-255. Amsterdam: North Holland.

Powell, O. and N. Shestakova (2016). Experimental asset markets: A survey of recent developments. Journal of Behavioral and Experimental Finance 12, 14-22.

Sapienza, P., L. Zingales, and D. Maestripieri (2009). Gender differences in financial risk aversion and career choices are affected by testosterone. Proceedings of the National Academy of Sciences 106(36), 15268-15273.

Smith, V. L., G. L. Suchanek, and A. W. Williams (1988). Bubbles, crashes, and endogenous expectations in experimental spot asset markets. Econometrica 56(5), 1119-1151. 
Stöckl, T., J. Huber, and M. Kirchler (2010, Sep). Bubble measures in experimental asset markets. Experimental Economics 13(3), 284-298.

van Boening, M. V., A. W. Williams, and S. LaMaster (1993). Price bubbles and crashes in experimental call markets. Economics Letters 41(2), 179-185.

Wang, J., D. Houser, H. Xu, et al. (2017). Do females always generate small bubbles? experimental evidence from us and china. Technical report. 